\title{
CIVIL SOCIETY ORGANIZATIONS (CSOs) PERSPECTIVE AND HAZE-FREE ASEAN 2020: EVIDENCES FROM RIAU
}

\author{
Alfajri $^{a}$, Azhari Setiawan ${ }^{a}$ and Herry Wahyudi
}

\begin{abstract}
Riau is one of the most forest and land fire-prone provinces in Indonesia. These forest and land fires cause haze pollution affecting not only Riau, but also the South-East Asian region. Even though Indonesia had ratified the ASEAN Agreement on Transboundary Haze Pollution (AATHP) in September 2014, the haze pollution in 2015 caused by forest and land fires had proven that the AATHP regime was ineffective to tackle haze issues in Indonesia, particularly in Riau. Relatively less forest and land fires and haze pollution in Riau (also across the nation) in 2016 and 2017 was by no means due to the implementation of the AATHP regime, nor by the Riau Province government policies. Rather, it is believed to be due to the heavy rainy seasons during those two years. The ASEAN haze-free agenda is very imminent now as we are entering Year 2020. This paper applies David Easton's theory of decision making which belongs to the behaviouralist approach. This article aims to discuss the demand and support aspects as the inputs to political and decision making process by the local government of Riau particularly, although the theory is also applicable to national and international decision making process. The findings of this paper show that CSOs have focused most of their attention on the demand aspect and has not yet provided significant change to the Riau government policies and local practices regarding land and forest fires, as well as haze pollution issues in the South-East Asian region. Therefore, there is an urgent need to balance the demand and support aspects towards the government decision-making process to resolve this perennial issue. This effort may be achieved by involving more sectors, including the Government and CSOs to collaborate sustainably with other sectors which researchers call as ABC-GIM: academics, business actors, CSO activists, Government Officials, Influential Individuals and Mainstream Media. This sustainable collaboration should provide a balanced aspect of demand and support in decisionmaking process which eventually may resolve transboundary haze issues in the short and long-term periods.
\end{abstract}

Keywords: Riau, Haze-free, ASEAN Agreement on Transboundary Haze Pollution (AATHP), Multi-sector Collaboration.

\section{INTRODUCTION}

ASEAN has set a roadmap to achieve a haze-free region in 2020 (Roadmap, 2016). However, looking at the imminent time that ASEAN has set to reach its target - less than a year from now, it is essential to look closer and deeper at the Riau Province that has

a Corresponding Author: Alfajri (alfajri@univrab.ac.id) and Co-Authors are Azhari Setiawan (azhari.setiawan@univrab.ac.id) and Herry Wahyudi (wahyudi@univrab.ac.id). Authors are Lecturers at the Department of International Relations, Faculty of Social and Political Sciences, Universitas Abdurrab, Indonesia. 
suffered from land and forest fires in Indonesia in the past few decades. The Riau Province is located in the middle of the Sumatera Island. It consists of a large area of peatland, an estimated 4,360,740 million hectares of the nearly 9 million hectares of its total land area (Alfajri \& Luerdi, 2016). Riau consists of two municipalities and ten districts and is very close to two South-East Asian neighbouring countries, Malaysia and Singapore. Due to this geographical proximity, any large-scale forest and land fires that occur in Riau usually affect these two countries.

The worst major outbreak of land and forest fires in the Riau Province prior to the outbreak in 2015 occurred in 1997. This 1997 fires affected several South-East Asian countries (Pakar: Asap Riau 2014). Meanwhile, the outbreak in 2015 occurred not only in Sumatra, but also in Kalimantan Island, stretching land fires haze pollution to reach far beyond Malaysia and Singapore as the regular affected countries, to Thailand, Brunei, the Philippines, Vietnam and even Cambodia (Sarmiento, 2015). The haze issue in Riau has drawn increased attention from local, national and international communities, particularly after the 1997 land and forest fires. However, for Singaporeans, this haze issue was nothing new, as they had been affected previously in 1972 and 1977, when their country was blanketed with haze suspected from land and forest fires in Palembang and other provinces in the Sumatera Island (Haze in Singapore, 2015).

Although unresolved, the haze problem, particularly in the Riau Province, seemed to be forgotten until a series of quite recent large-scale forest and land fires took place in 2013, 2014 and peaked in 2015. Riau, Palembang and Jambi once again became spotlights in the media together with several other provinces in Kalimantan. These three consecutive years (2013, 2014 and 2015) of haze outbreaks had not only received attention in the regional media, but became a global media outcry, from Russia to South Africa, from United States to Australia (Singapore Smoke, 2013; Smog Returns; Aw, 2015; Malaysia Closes, 2013). The 2015 land and forest fires, which Riau also contributed to, was estimated to have caused the highest losses, even compared to the 1997 outbreak, with a total figure of 200 Billion Rupiah (Lestari, 2015) and claimed the lives of 19 victims, where 5 of them were from the Riau Province (Akuntono, 2015, Haryanto, 2016). Going into 2016, 2017 and 2018, to a lesser degree, land and forest fires still took place in the Riau Province, although it did not cause a global or regional outcry as the haze pollution affected mainly the Riau Province, slightly touching Malaysia and Singapore as its regular victims (Warsito, 2018; Safutra, 2017; Jerome, 2016). As the latest update on this issue, it was reported that as of July 2019, 3,517 hectares of land and forest fires occurred in the Riau Province (Indriani, 2019). The conflagration affected land and forest areas in 11 out of the 12 districts and municipalities in Riau in the month of July (Perwitasari, 2019). Meanwhile, in the preceding month of June 2019, land and forest fires occurred in all 12 districts and municipalities across the Riau Province (Tanjung, 2019).

Looking at this unresolved issue, regional and international communities raised the question as to what has really been done by the local governments to overcome this perennial problem and to achieve the ASEAN haze-free 2020 target? Due to significant international pressure and national outcry, the 2013 and 2014 haze outbreaks had pushed 
the Riau Government to issue the 2015 Gubernatorial Regulation Number 5 which included several key activities. In 2018, the Riau Governor had also signed the local (provincial) 2018 Regulation Number 10 regarding Riau Province Spatial Plans. However, this effort had gained critics from local civil society organization, Jikalahari, which stated that this regulation was not in line with the higher regulations, and was proelite businesses, and thus, did not portray serious efforts in ensuring the protection of ecology governance (Yugo, 2018). The legalization of these two local-level policies has not yet brought any long-term or short-term solution to the haze problem. Therefore, this paper tries to look at this issue from CSOs' perspective using the David Easton theory. How far is the effectiveness of the demand and support that have been made and given by CSOs, including external pressure, in influencing government policies? This paper also offers other solutions, in addition to what have already been implemented, to meet clear objectives or solutions both in short or long-term projection. This paper will also further discuss details on what the ASEAN haze-free target may look like in 2020.

\section{LITERATURE REVIEW}

The study of transboundary haze spreads out from the "national and regional" contexts to the "policy and mitigation" scales and intensity. Therefore, the existing literature can be mapped into the table below by the level of analysis: regional, national, and local public issues. This table can be used to analyse the scope of transboundary haze issues, the level of political context, and the area of study that can be examined in the future. This article groups international and regional as one category. A specific phenomenon in a particular state such as in Indonesia, Malaysia, and Singapore can be categorized in this group of studies. National level refers to the study in a particular country or the study that uses country level as the case. Finally, local level stakeholders, corporations, and civil society groups act as the focus of study.

This research observes ten journal articles published between 2013 and 2017 by various reputable international journals which can be categorised into three groups namely, international/regional, national, and local level (public) of analysis. The table below shows the following result: four of the contemporary samples of literature analyse transboundary haze by using international or regional contexts (ASEAN), either in studying this phenomenon worldwide or assessing a particular region or group of countries. Most of them actually discuss the unique case of ASEAN mechanisms on transboundary haze. Interestingly, five of them focus their studies on the national or state scale policy, public concerns, risks, potential threats, and so on. Lastly, only one of these journals examines the existence of transboundary haze in the local political context including public health. 
Table 1. The Study of Transboundary Haze from Local to International Level

International / Regional

- Gabrielle SIMM, 2016 (ASEAN); Sarah Tan Yen Ling, 2017 (ASEAN); Janic Ser Huay Lee et.al, 2015 (ASEAN); Ku Mohd Kalkausar Ku Yusof et.al, 2017 (ASEAN)

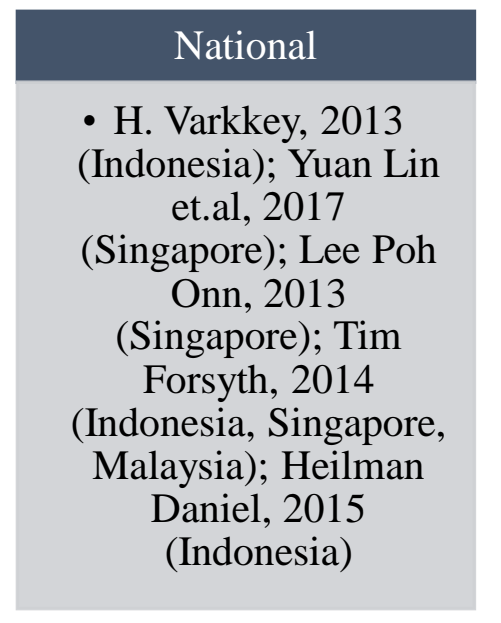

As mentioned earlier, at the international or regional level, researchers are interested in analysing the AATHP mechanism in ASEAN which can be seen from the research by Tan and Ling (Tan \& Ling, 2017), and there are also researchers who connect the transboundary haze problem with the causes of dispute mitigation at regional level and history of deforestation in ASEAN as explained by Kuh Mohd (Mohd et al., 2017). The relationship between local and regional patron politics in the effort to mitigate transboundary haze can also be seen from the research by Janice Ser (Ser et al., 2016). Finally, the interesting research at this level is the journal by Gabriell Simm (Simm, 2017) which analyses the response to disaster management in the ASEAN region by comparing several disasters that occured in ASEAN, such as the 2004 earthquake and tsunami disasters in Indonesia, Malaysia, and Thailand, cyclone Nargis in Myanmar in 2008, and typhoon Haiyan/Yolanda in the Philippines in 2013. This study also explains the role of non-state actors in disaster mitigation efforts in ASEAN.

At the national level, there are five research that analyse the condition of countries in ASEAN in the face of transboundary haze, including their challenges and constraints. The challenge of regional political patron relations in Indonesia in an effort to open new plantation land can be seen in the research by H. Varkkey (Varkkey, 2014). The correlation between the environment, especially the transboundary haze problem on the social and economic aspects in Singapore and Malaysia, can be seen in the journal by Lin (Lin, Wijedasa and Chisholm, 2015). Lin et.al analyse the effects of transboundary hazards on social and economic activities in Malaysia and Singapore which resulted in a decline in trends when the haze disaster occurred. Haze disaster relations with decentralization in Indonesia are explained by Lee Poh (Lee Poh Onn, 2013). Political analysis related to the analysis of news frames on transboundary haze cases in Indonesia, Malaysia and Singapore is explained by Tim Forsyth (Forsyth, 2014). Whereas, the reason why Indonesia ratified AATHP to carry out this mechanism is explained by Heilmann (Heilmann, 2015). Finally, the journal that analyses at the local (public) level about the development of regional environmental degradation, institutional capacity, and 
the health impacts on transboundary haze can be seen in the journal of Nazzer Nazia (Nazeer et al., 2017).

The table of the map of literature above has some relevance to this area of study. Firstly, at the international/regional level, the focus of previous research has been in applying the AATHP mechanism. Secondly, at the national level, previous research has provided numerous information and analysis on the political situation of a country in responding to haze problems, and on the challenges and constraints in implementing haze disaster mitigation efforts in each of the countries. Third, at the local / public level, the focus of research has been at the level of health issues, thus the output of policies that should appear at this level has not been rigidly explained. Lastly, all of these research provide information and inspiration for the researchers to further analyse the existence of non-state actors, especially civil society groups, in assessing the transboundary haze problem along with the role of the groups.

\section{DAVID EASTON'S THEORY IN DECISION-MAKING PROCESS}

The theory used in this study is the analysis of the political system proposed by David Easton, i.e. applying the behavioralist approach in the analysis of political systems - a Decision-Making Process Theory that can be applied at the local, national and international levels. Easton's analysis explains the concepts of demand and support, the political system (the behaviour or actions of the authorised actors) and outputs (policies or decisions) for how political systems and structures work. The research analyses the sub-national role towards international issues in the local context. Local policy and decision-making process then become the main discussion. By applying David Easton's Decision-Making Process Theory, we aim to explore the input - particularly on demand and support aspects, process, and the output of the policy regarding land and forest fires, as well as haze-related issues that affect the ASEAN region at the international level.

By applying the David Easton theory, the researchers also acknowledge that the analysis used is in line with David Easton's assumption which considers a political system as an individual unit into which persistent inputs flow (David Easton, 2008: 5). The flowing inputs through demand and support ensure the system works continuously. The inputs are changed into outputs by following the process within the system which may affect or influence the system or its environment. Eventually, it is also expected to influence the inputs through feedbacks (Easton, 2008, p. 5). 
The following illustrates the David Easton's System Theory:

Diagram 1. David Easton's Decision-Making Theory (Alfajri \& Luerdi, 2016)

Environment

Environment

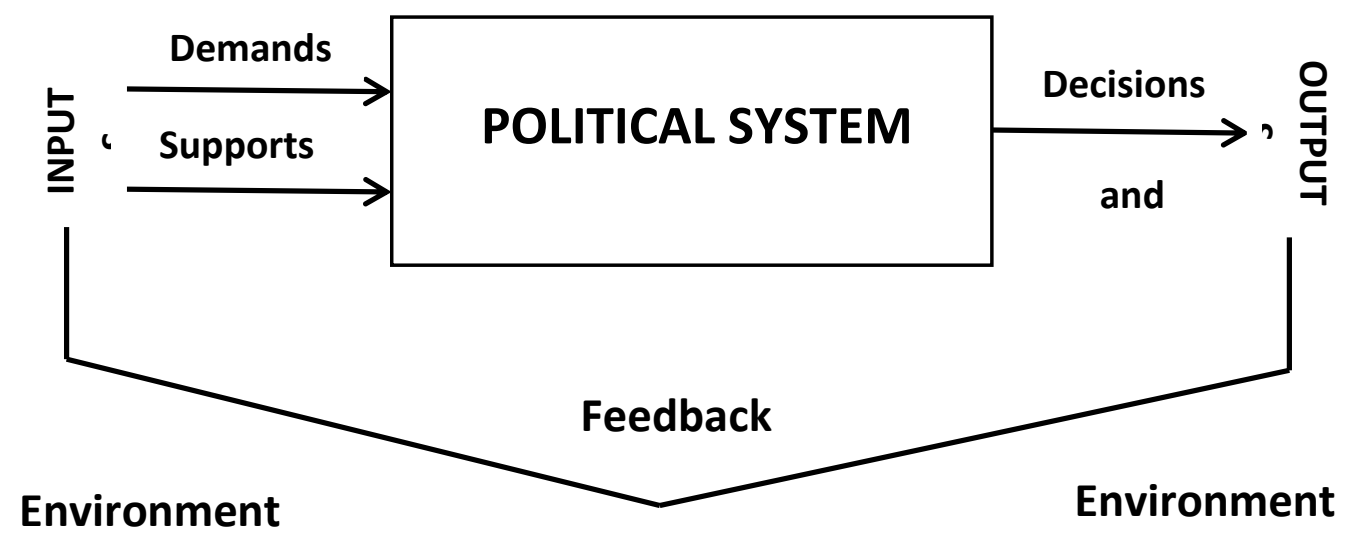

By referring to the above illustration, this paper can reveal the decision-making process which involved the local government of Riau at the Provincial level with regard to the policies issued after the national government ratified the AATHP in order to implement the goals of the AATHP. The process can be explained as follows:

First, the phenomenon of land (peatland) and forest fires that occurred in Riau for years reached the worst situation in 2015 causing severe haze pollution and environmental damage. Many economic and human activities were disrupted. Children and women were also afflicted with health problems - there were even fatalities in this incident. Schools were closed to protect students from health problems caused by air pollution from haze (Riau Pos, 2016). Grassroots responses were raised from various local groups derived from CSOs and local communities such as Walhi, Jikalahari, Riau Melawan Asap, as well as student movements from several higher education institutions who made demands to the provincial government (Riau Aktual, 2016). The demands were expressed in various forms, including continuous street public protests that lasted for weeks, putting pressure on the governor to issue policies to immediately handle the problem and overcome the horrendous damages caused by haze. Their demands were also conveyed in other forms such as public talks, dialogues and intellectual criticism through media. There is no doubt that the local, national and international media's coverages over the haze outcry played a role in raising public awareness, increasing the pressure over the local government to take appropriate action. 
The Indonesian central government's position as the country's representative which enters into agreements at ASEAN regional level and held responsible at the national level, is the first party to be liable to solve the land and forest fires, as well as the haze pollution within its territory according to the AATHP. However, at this stage, the Indonesian central government, who had already ratified the AATHP, had also pressured the local governments to take prompt and appropriate action regarding the land and forest fires (Burhani \& Salim, 2019). Sometimes, the central government also blamed the local governments over their inability to deal with this issue (Hutan Terbakar, 2016). It is crucial to comprehend that after the demise of President Soeharto, and the inception of the regional autonomy, there were a lot of new regulations introduced by the central government, and one of the new regulations was that the environmental sector had become a joint-responsibility affairs between the central and local governments, both at the provincial and the regency levels (Mina, 2016). Therefore, as the land and forest fires occured at the local level, the national government expected the local governments, as sub-ordinates in the Indonesian governmental system, to anticipate and react appropriately and professionally. However, at the same time, the local governments also expected the central government to provide significant aid in a complex haze disaster.

The forest and land fires in Riau had caused haze pollution and potential transboundary haze affecting and disturbing neighbouring countries. Both Singapore and Malaysia had stated their disappointments towards the Indonesian government, particularly by mentioning Riau not being able to tackle the forest and the land fires, as one of the main sources of the haze. Besides these two closest neighboring countries, other ASEAN countries and the international society had also expressed demands in the form of criticisms. This inevitably had put more pressure upon the local government of Riau.

Secondly, despite the demands from CSOs and community movements that were explained earlier, input also came in the form of support from the central government. The central government's reliance on the local governments in the form of cooperation and coordination was expected to run smoothly. Collaborative works and synergy between the central government and the local government theoretically would provide better solutions to resolve the forest and land fires. However, the joint-responsibility affairs between the government and the local governments in the environmental sector could sometimes become a weakness as well as each side expects more from the other.

Thirdly, both demands and supports delivered are to be processed within a boxlike political system. The process is described as actor's behavior or action. In this case, the Riau government as the actor in the system is part of the national unity which must ensure itself to work collaboratively with its upper-level government, that is, the central government. The collaborative works and coordination are mainly related to fire reduction, management of risks and any future potential land and forest fire prevention within its area by issuing relevant local policies or decisions. The final result are aimed both for the purpose of domestic need and the ASEAN AATHP implementation.

Both the demands and supports derived from multi-sides regarding the land and forest fires are necessary for taking actions. These actions need to be processed and 
executed properly so that the local government may obtain trust from the public. As an authorised local decision maker, the Governor had issued the plan of action to prevent the land and forest fires (Alfajri \& Luerdi, 2016). The Governor did not stop there, he was also liable to raise the statuses of emergency within his authorised area. The former was integrated and incorporated in the Gubernatorial Regulation Number 52015 (Alfajri \& Luerdi, 2016). Meanwhile, the latter was then followed by the formation of a task force to tackle the haze disaster caused by the land and forest fires. This task force is an ad hoc body, then expected to fight the land and the forest fires, as well as the haze. The Riau local government had expected that those policies issued could contribute to the implementation of the AATHP within its authorised area as demanded by the CSOs, the public and particularly, the central government.

The following illustrations describe the decision making and sequence of the policies:

Diagram 2. Illustration of Riau Government Decision Making Process (Alfajri \& Luerdi,

- Demands (local, national and regional actors' pressures)

-Supports (domestic and national level) 2016)

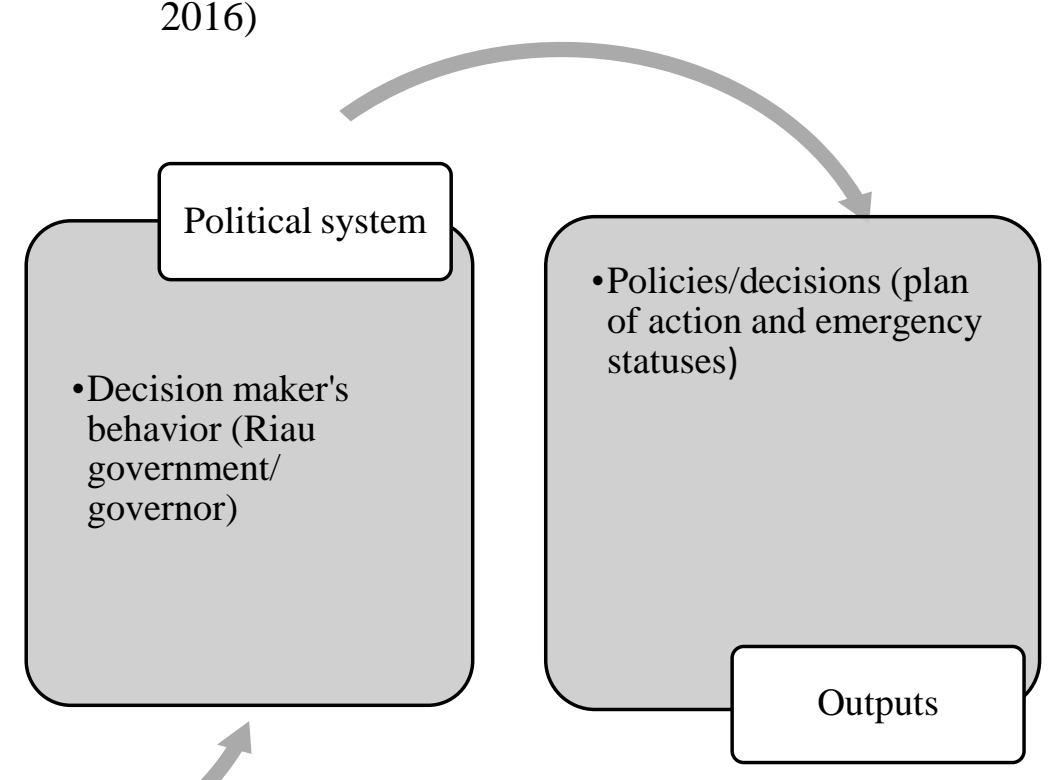


Diagram 3. Illustration of sequences of Riau Government Policies (Alfajri \& Luerdi, 2016)

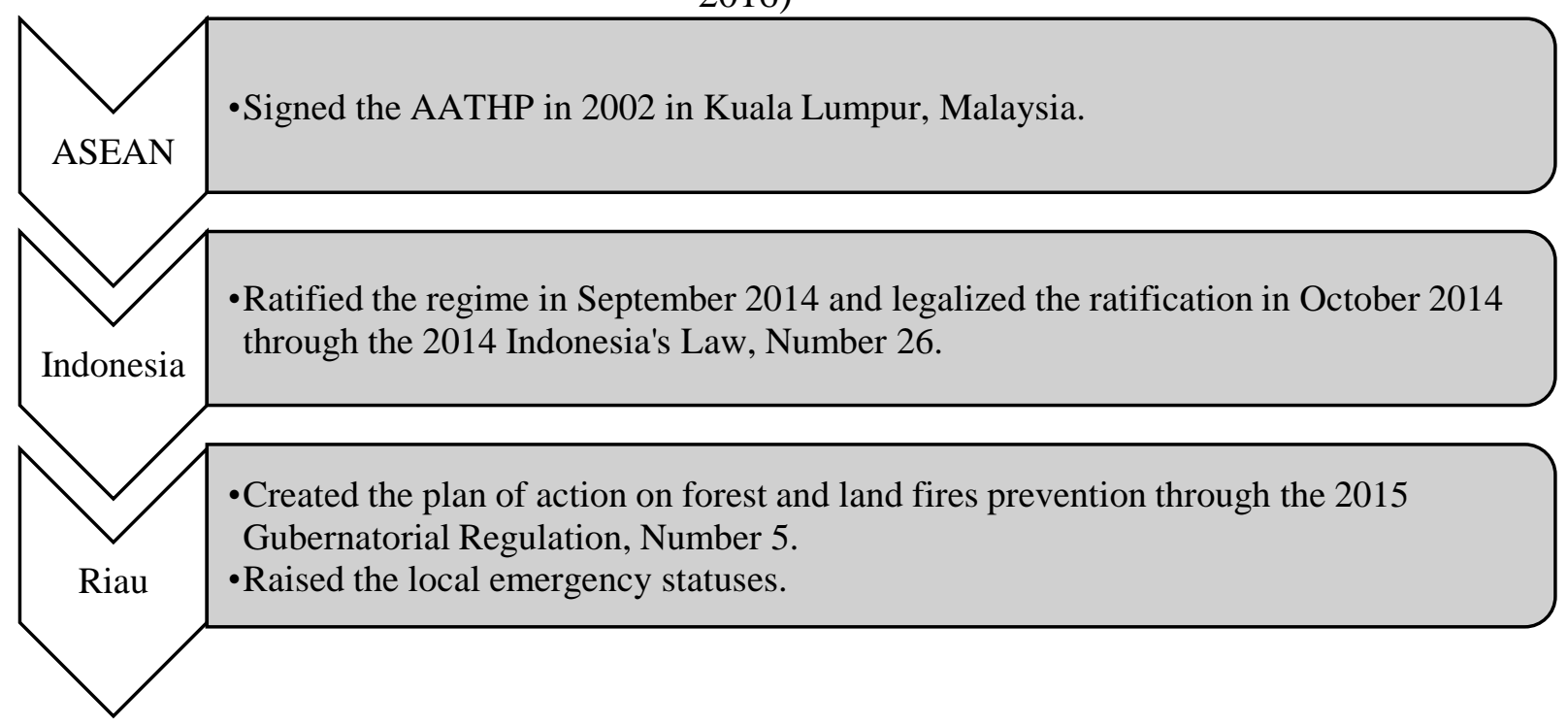

In addition, in the case of land and forest fires in Riau which mostly are followed by peatland fires, there are many cases which are caused by big concessions or big plantation corporations, but most of the times, the people, the small holders and individuals who are often blamed and punished by the law. Meanwhile, big concession owners and big plantation corporations which are often seen to be the culprits of the forest and land fires are usually in a favorable position (Fahmi, 2015; Hardum 2016; Pratama, 2016; Hidayat, 2016; Hermawan \& Fadhilah, 2016). The peak of the public distrust towards the Indonesian law enforcement towards the big plantation corporations or big concession owners was in regard to the issuance of the letter of the termination of investigation by the Indonesian National Police office (Erdianto, 2016). The letter of the termination of the investigation was believed by the public to be issued by the Police after several high-ranking national and local police officers met with an accused and suspected big plantation businessman executive - pictures of whom went viral in social media (Akbar, 2016; Zuhri, 2016). This event was acknowledged by an Indonesian high ranking National Police officer, however he denied that the encounter had influenced any decision on the outcome of the investigation process (Erdianto, 2016). Missing links in cases of peatland expansion can also be seen in the policies of the Riau regional government regarding the 10/2018 RTRWP on the allocation of land space in Riau $2018-2038$. This policy does not seem to exhibit any synchronous decision and policies between demand and support in the political system as theorized in the Easton's analysis. 
Picture 1. RTRW (Spatial plans) in Riau

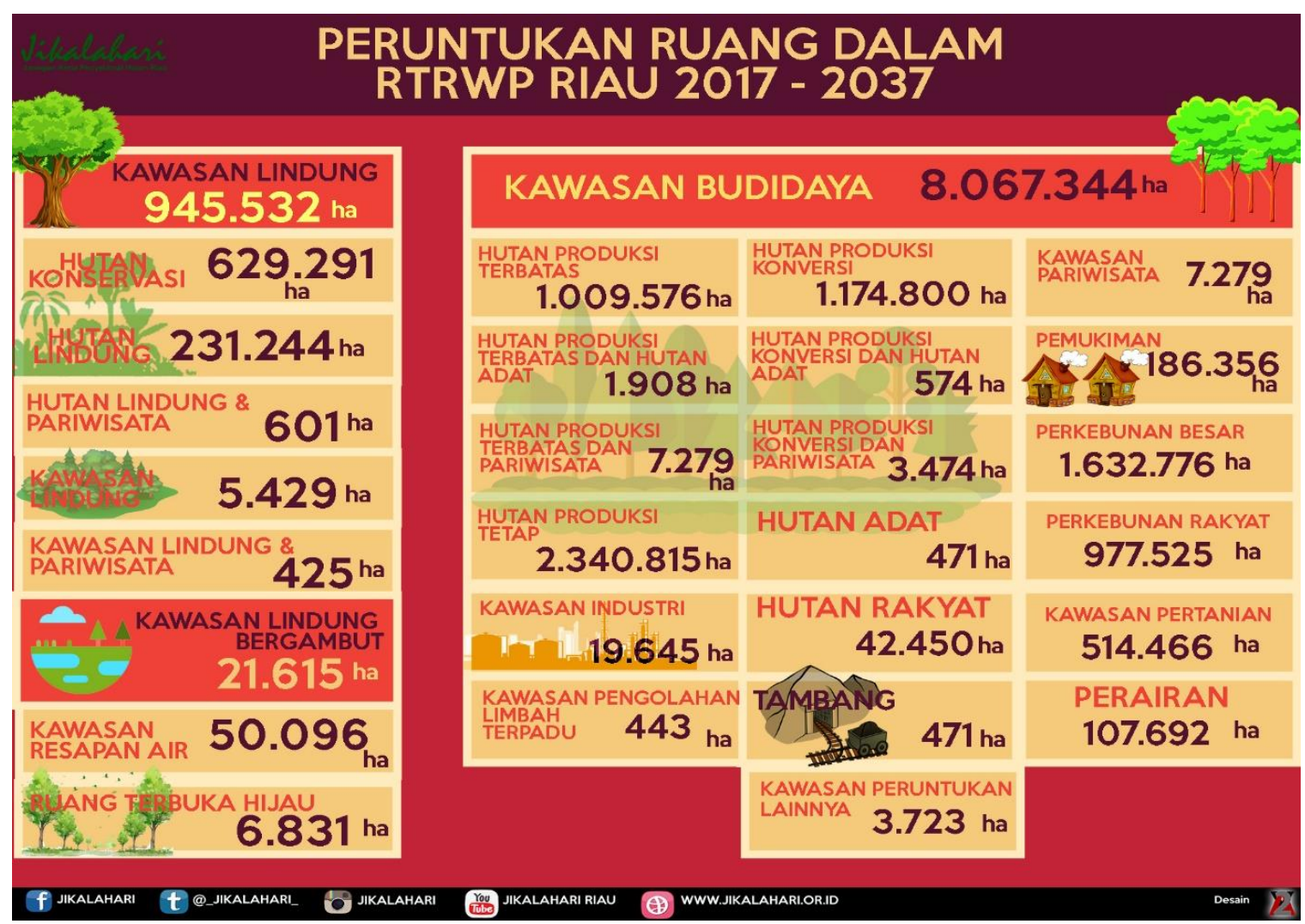

Source: Jikalahari on Focuss Group Discussion, Civil Society Perspective Regarding ASEAN Haze-free 2020. Universitas Abdurrab, Pekanbaru, Riau. October 02, 2018.

Local regulations in Riau do not reflect the environmental conditions of their own regions, with more than 8 million hectares cultivated areas (including those controlled by concessions), while protected areas are only 900 hectares. Crucial issue of regulation 10/2018 2018-2038 RTRWP also describes findings on the outlined map that the land that was allocated for the people (bleached) in the field was controlled by the oil palm barons as can be seen in the following figure: 
Picture 2. RTRWP (Spatial plans amendment) in Riau

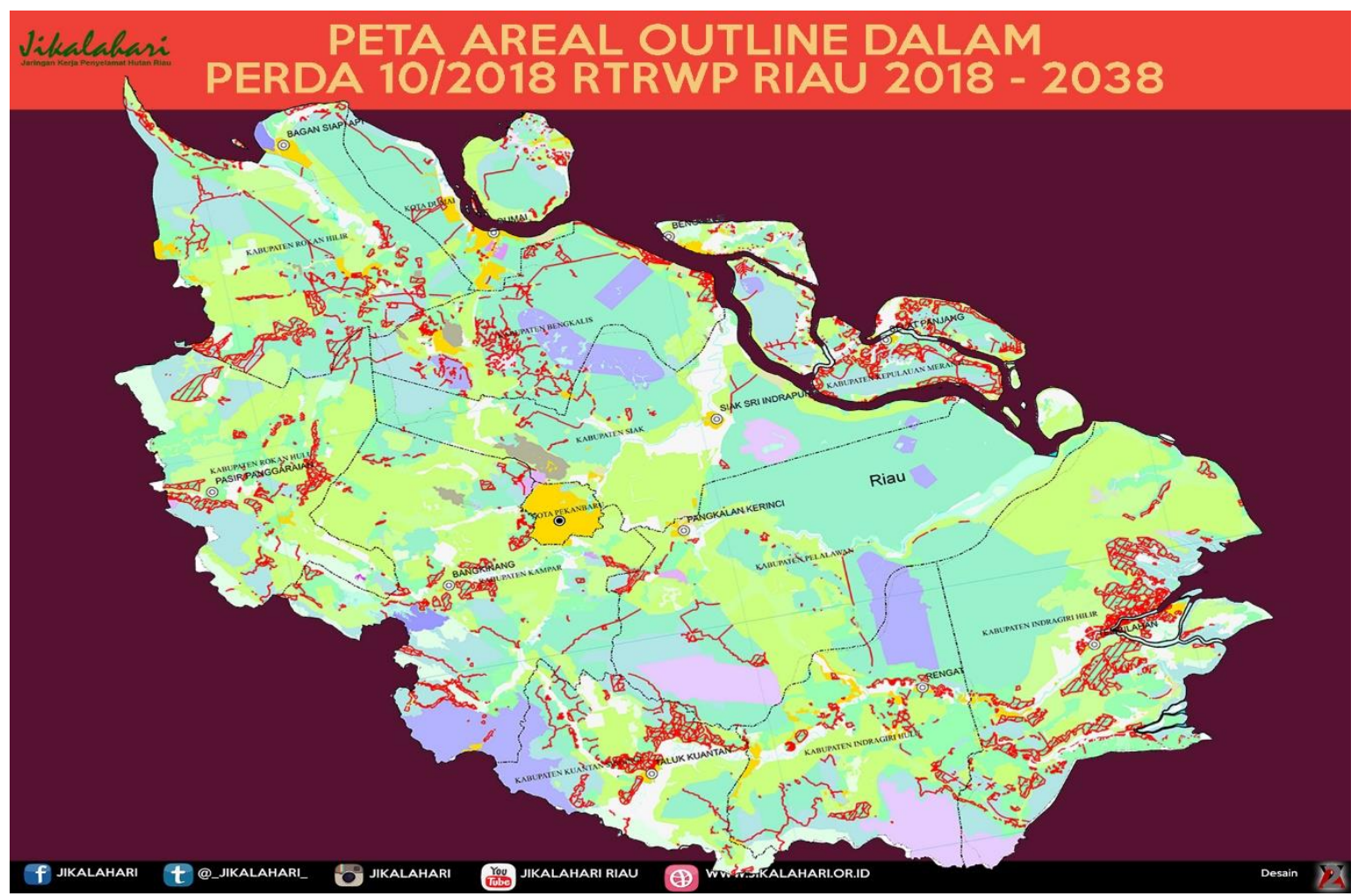

Source: Jikalahari on Focus Group Discussion, Civil Society Perspective Regarding ASEAN Haze- free 2020. Universitas Abdurrab, Pekanbaru, Riau. October 02, 2018.

\section{METHODOLOGY}

Based on the theoretical framework, the research problematizes the input section of David Easton's theory being the demand and support. We explore how CSOs play the role as one of the main sources for the demand and support of Riau Government decisionmaking process on haze and haze-related issues.

The research could be classified as an explorative research which applies qualitative analysis approach, especially the phenomenology method. The participants for the purpose of collecting data consist of several environmental civil society organizations (CSOs) in the Riau Province. We invited several delegations from environmental NonGovernmental Organizations (NGOs) and disaster research center (Pusat Studi Bencana) in Riau to conduct a focus group discussion (FGD). The FGD took place at Universitas Abdurrab, Pekanbaru, Riau Province. The invited environmental CSOs were Pusat Studi Bencana Universitas Riau (PSB, Universitas Riau), Wahana Lingkungan Hidup Riau (Walhi Riau), Jaringan Kerja Penyelamat Hutan Riau (Jikalahari), Forum Indonesia untuk Transparansi Anggaran (FITRA) Riau, and Himpunan Penggiat Alam (Hipam) Riau. 
The method focuses on CSOs' perspectives towards the Riau Government and Haze-Free ASEAN. We extracted the CSOs' points of view towards the implementation of the AATHP regime by the Riau Government, an agreement which had been ratified by the Indonesian Government into Undang Undang No. 26 Tahun 2014. Outside pressures have yet to provide any significant changes to the Riau Government policies and local practices regarding peatland fires and haze pollution issues. We assume that there are greater opportunities to enhance a sustainable collaboration with the local government and society to resolve these transboundary issues for short and long-term periods. Our assumptions also deliver an understanding that the sustainable collaboration extends in multi aspects spanning from law, social, health, economy, education, and security. The FGDs were conducted to map flourishing discourses on transboundary haze narrations, especially in Riau Province as one of the most peatland fire-prone areas in Indonesia. Methodologically speaking, our aim is to draw those assumptions and those flourishing discourses in between. To map the discourses and dig the narrations up to the ground, we prepared the following key questions:

1. What are the factors that have been the major causes of haze problems in Indonesia, especially the Riau Province, from CSOs' and other related parties' points of view?

2. What are CSOs perspectives towards ASEAN Haze-free Roadmap 2020?

3. To what extent, have the Government (central, provinces, and districts) efforts achieved ASEAN Haze-free Roadmap 2020?

4. What are CSOs' recommendations to solve the land fire, haze crisis, and generally other aspects of sustainable development agenda?

5. What are CSOs' challenges and obstacles in fighting haze problems and in solving them and other environmental issues?

These key questions were delivered to draw an analytical induction and thematic analysis. The analytical induction was delivered to find the universal explanation and data exploration. The thematic analysis was delivered to categorize, qualify, and classify the data into theme clusters which have been extracted from the theoretical framework. We also deliver triangulation of the data and analysis. The qualitative data and insights are triangulated with some statistical data (e.g. Palm Oil Plantation, Pulpwood Concession: Hutan Tanaman Industri: HTI, Licensed Logging Concessions: Hak Pengusahaan Hutan: HPH), peatland data, fire spots, haze maps and statistics, etc.) and interviews with key persons relevant to the topic and problems under discussion.

\section{RESULTS AND DISCUSSION}

Haze problems, particularly in Indonesia, cannot be separated from discussions on CO2 Emission, Peatlands, Deforestation, Palm Oil Companies, Pulpwood Concessions (HTI), and illegal plantation on forbidden and protected areas. Based on the World Bank Open Data, CO2 Emission are those stemming from the burning of fossil fuels and the manufacture of cement. They include carbon dioxide produced during consumption of solid, liquid, and gas fuels and gas flaring (World Bank Open Data, 2018, accessed from https://data.worldbank.org/indicator/EN.ATM.CO2E.KT). 
Indonesia is facing environmental challenges. Fire from drained peatlands results in air polluted with smoke, causing respiratory diseases. Disruptions to economic activities brought about losses amounted to USD16 billion. This amount is twice as large as the losses and damages caused by the 2004 tsunami in Aceh - equivalent to $1.8 \%$ of Indonesia's Gross Domestic Product (GDP). This estimation includes losses in agriculture, forestry, transportation, trade, industry, tourism and other sectors. Part of the losses is due to direct damage and loss to crops, forestry, housing and infrastructure, and costs incurred to deal with fire. (World Bank, 2015, accessed from http://www.worldbank.org/in/news/feature/2015/12/01/indonesias-fire-and-haze-crisis).

Many economic losses are caused by indirect impacts, such as disruption of air, sea and land travel due to smoke. The impact on local GDP growth is predicted to greatly affect economic growth and government efforts to alleviate poverty in the most severe areas, such as Riau and Central Kalimantan.

Forest and land fire, especially in peatlands produce very high concentrations of greenhouse gases (GHG). In addition, burned land loses its potential to re-absorb greenhouse gases, especially $\mathrm{CO} 2$. The increasing GHG concentration causes global warming to impact climate change. Guido van der Werf in his research which was posted by Global Fire Emissions Database (GFED), as well as reported by ecobusiness.com , stated that Indonesia's CO2 emissions have been equaled to one-million-dollar ton (higher than Germany's). Since early September, forest fires in Indonesia have generated carbon up to 15-20 million ton per day which exceeded United States' 14 million/day. (Tempo, 19 October 2015, accessed from https://nasional.tempo.co/read/710972/emisikarbon-dari-gas-kebakaran-hutan-ri-melebihi-amerika/full\&view=ok). 
Figure 1. Indonesia, Malaysia, and Singapore CO2 Emission (kt)

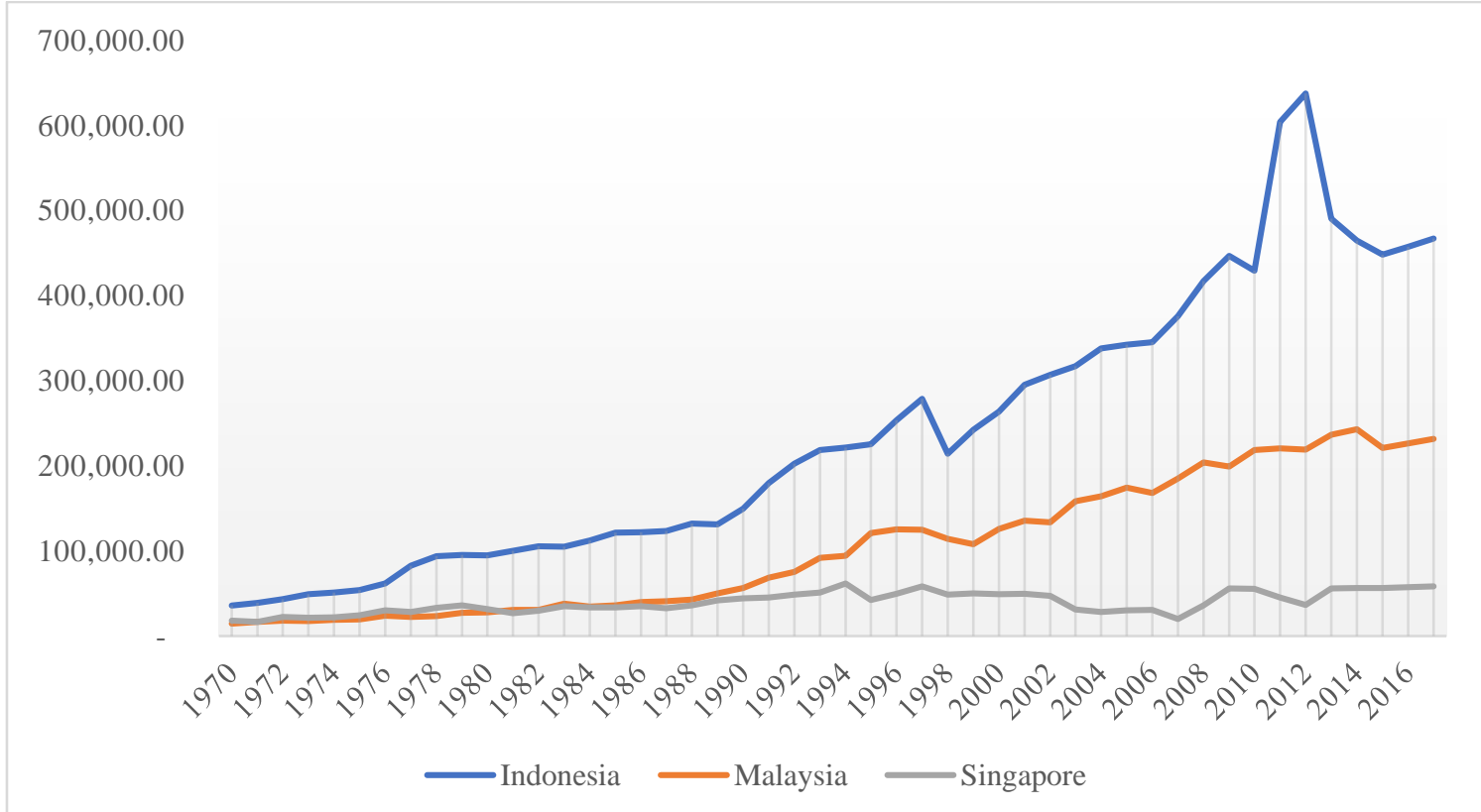

Source: Abstracted from Carbon Dioxide Information Analysis Center, Environmental Sciences Division, Oak Ridge National Laboratory, Tennessee, United States; World Bank Open Data, CO2 Emissions (kt), accessed from https://data.worldbank.org/indicator/EN.ATM.CO2E.KT

Indonesia has been a country with the highest number of $\mathrm{CO} 2$ emission since 1970 until today, and the graph shows that the CO2 emissions by Indonesia, Malaysia, and Singapore increased simultaneously over the observed period. Based on Figure 1, the first above-average number of CO2 emission was in 1985 in the amount of 121,245.69 kt and the first highest peak was in 1997 in the amount of 278,659.00 kt. Briefly after the Asian economic crisis, the $\mathrm{CO} 2$ emission of the three countries raised to the second peak in 2009 in the amount of 446,409.58 kt. The first peak of CO2 emission evidently also occurred in the period of economic crisis.

The high records of CO2 emission in Indonesia since 1970 were strongly related to peatland and forest fires. Picture 3 shows that between 2001 and 2017, there was a huge increase of land and forest fires in Sumatra. In 2001 there were only few fire spots, but in 2017, the fire spots were almost everywhere. This map, showing NASA's MODIS data, gives an indication where fires occurred throughout each of the calendar years since 2001. A hotspot on the map indicates that one or more fires burned within a $1 \mathrm{~km}^{2}$ area at the indicated spot (Eyes of the Forest, 2018). 
Picture 3. Detected Fire Spots in Sumatra 2001-2018

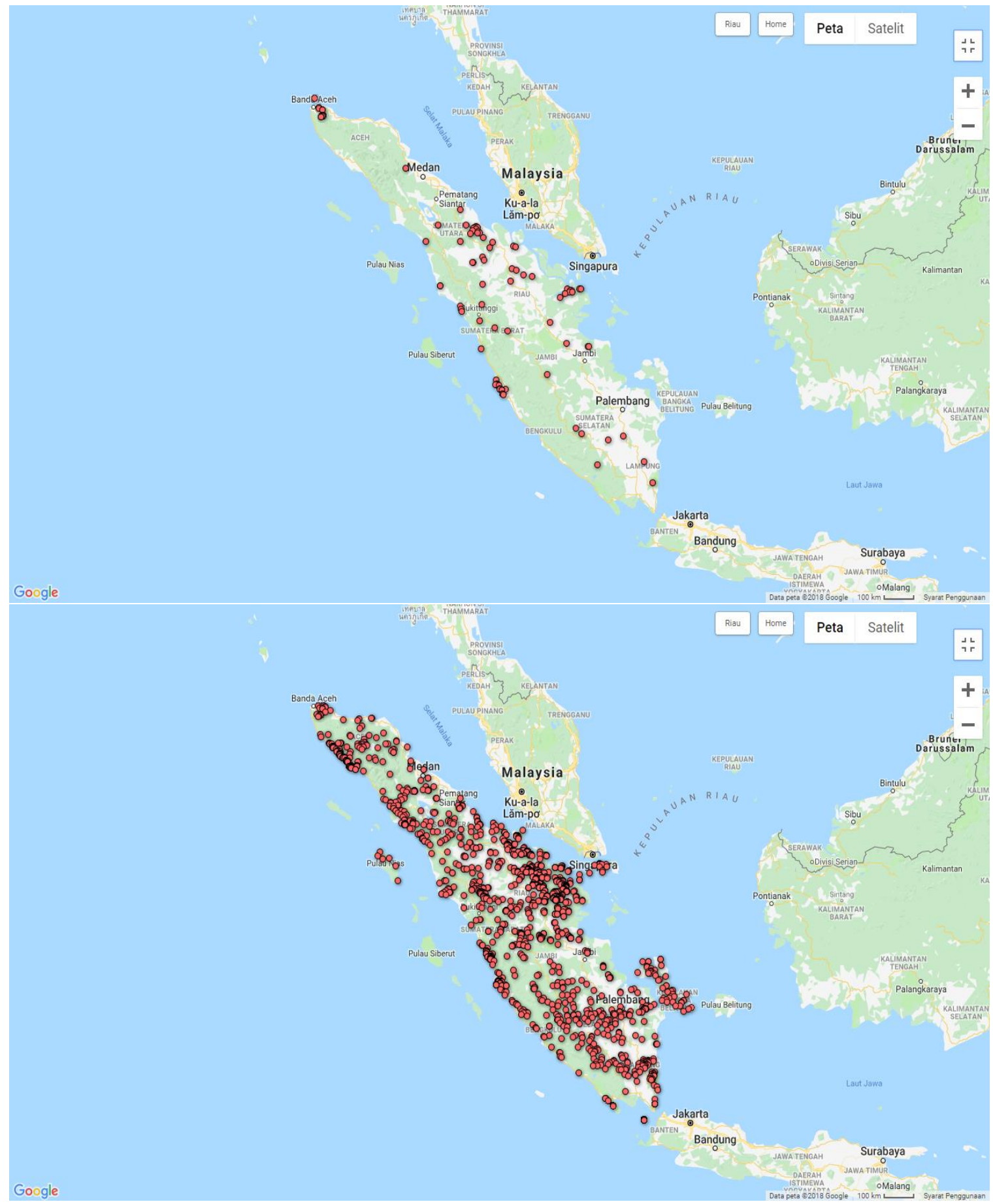

Source: Eyes on the Forest, "Sumatra's Forests, their Wildlife, and the Climate Online Database", accessed from http://maps.eyesontheforest.or.id/ on October 10, 2018; original data is available in NASA, Earth Data on Active Fire Data, accessed from https://earthdata.nasa.gov/earth-observation-data/near-real-time/firms/active-firedata\#tab-content-6 on October 11, 2018. 
Sumatra was the island with the fastest deforestation rate, with Riau as the top deforestation province in Indonesia. Between 1985 and 2009, Sumatra lost 48\% of its natural forest cover as shown in Figure 2. In 2014 a loss of 55\% was recorded. Sumatra's 44 million hectares mainland was covered by 25.4 million hectares of natural forests in $1985(58 \%)$ and 11.5 million hectares (26\%) in 2014. Sumatra lost 55\% of its forest over 29 years, cleared at an average rate of 480,000 hectares per year (1.9\%). Deforestation continued at a high rate. (WWF Indonesia, 2010; Eyes of the Forest, 2017).

Figure 2. Deforestation in Sumatra 1985-2014

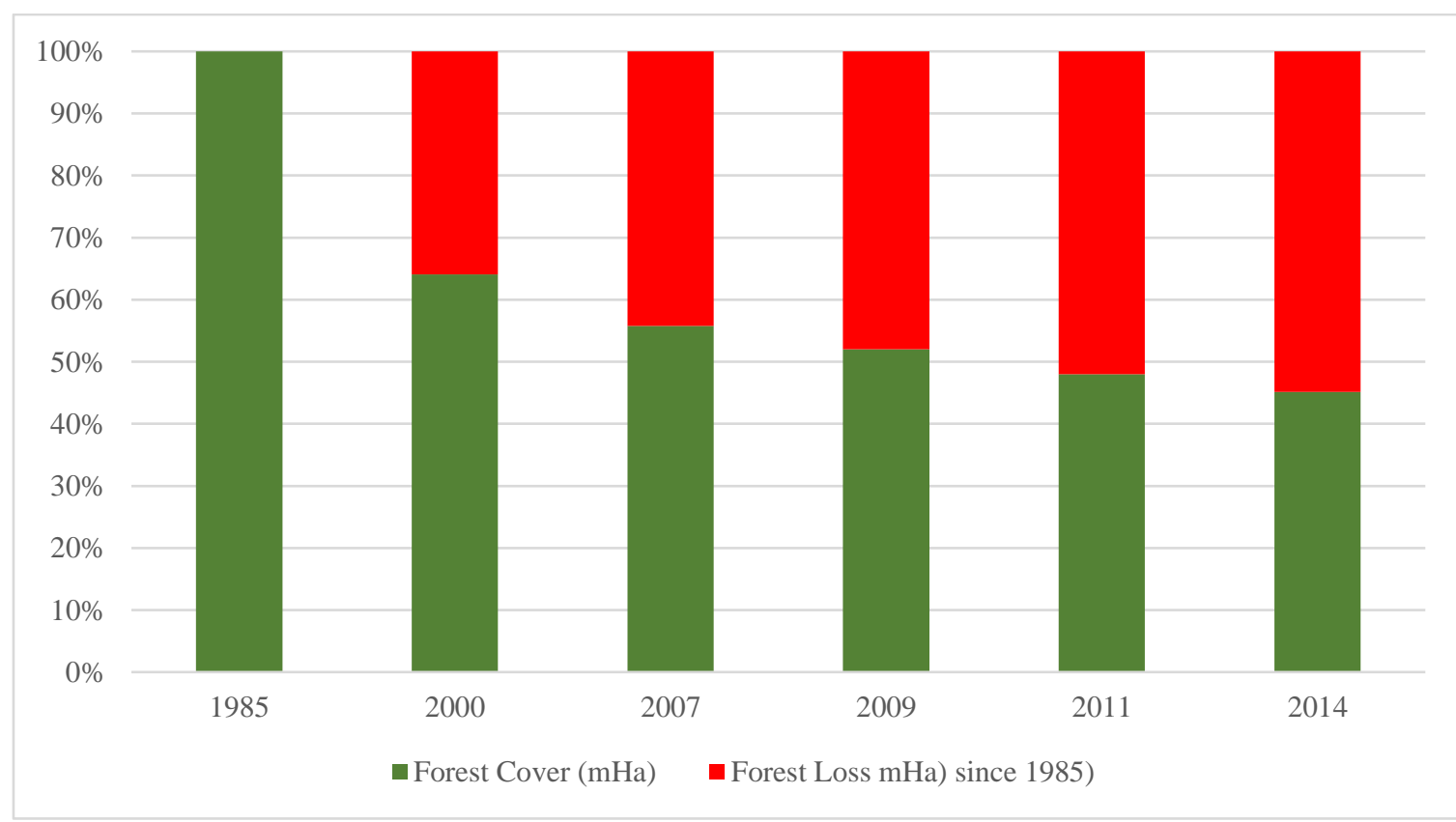

Source: Abstracted from Yumiko Uryu et. al, Sumatra's Forests, their Wildlife and the Climate (Jakarta: WWF Indonesia, 2010); Eyes on the Forest, 2018, "Sumatra's Forests, their Wildlife, and the Climate Online Database", accessed from http://maps.eyesontheforest.or.id/ on October 10, 2018.

High demand for national and global paper and palm oil commodities is the major causes of deforestation. The key deforestation drivers in Indonesia were (1) pulp and paper industry, which is dominated by APP and April with their suppliers as shown in Figure 3 and (2) palm oil companies which are dominated by RGE, Sinar Mas, Astra, etc., as shown in Figure 4. 
Figure 3. Pulpwood Concessions (HTI) in Sumatra 2017

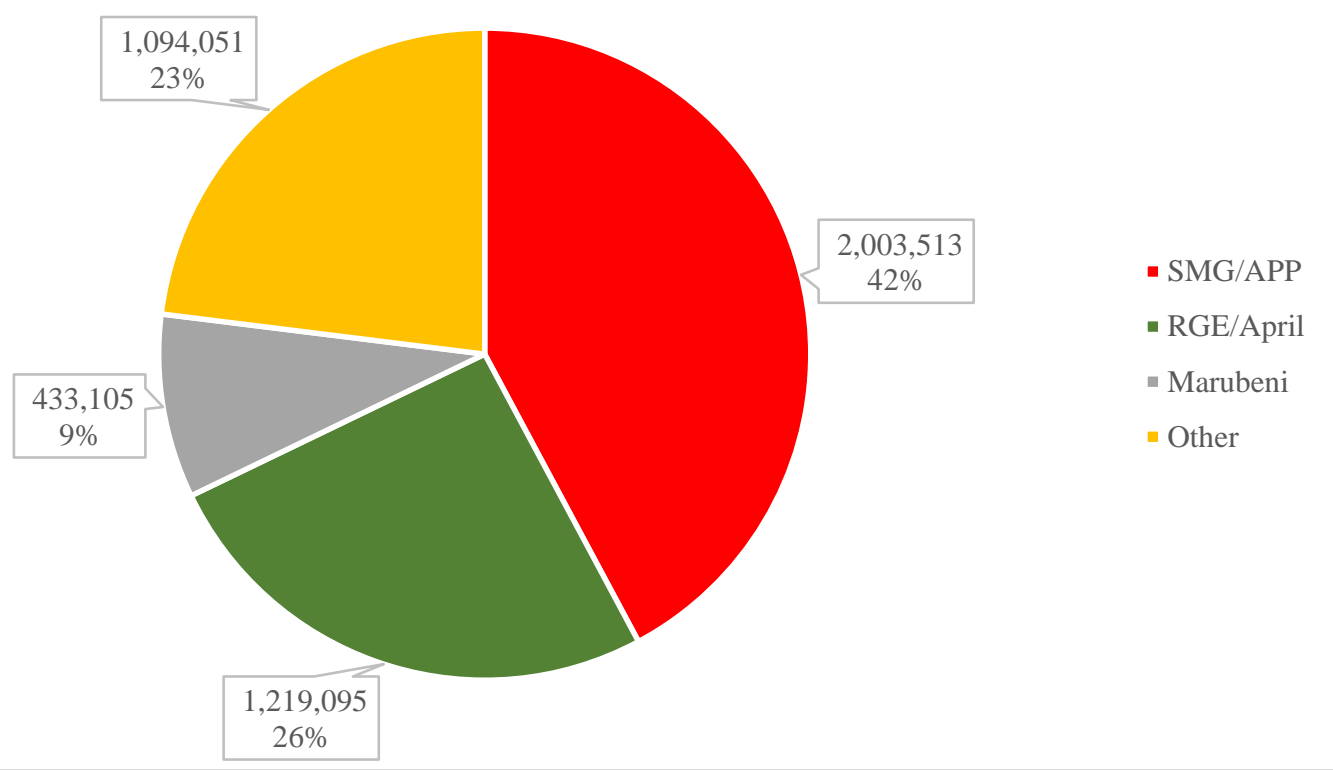

Source: Abstracted from Eyes on the Forest, 2018, "Sumatra's Forests, their Wildlife, and the Climate Online Database", accessed from http://maps.eyesontheforest.or.id/ on October 10, 2018; Ministry of Forestry, Peta Indikatif Arahan Pemanfaatan Hutan pada Kawasan Hutan Produksi yang Tidak dibebani Izin untuk Usaha Pemanfaatan Hasil Hutan Kayu (Jakarta: Kementerian Kehutanan, 2014); Ministry of Forestry, Buku Basis Data Spasial Kehutanan 2013 (Jakarta: Kementerian Kehutanan, 2013); Ministry of Forestry, Buku Basis Data Spasial Kehutanan 2014 (Jakarta: Kementerian Kehutanan, 2014.

As shown in Figure 3, Sumatra has a total of 4.8 million hectares of pulpwood concessions. The top groups are Sinar Mas Group/Asia Pulp \& Paper (SMG/APP), Royal Golden Eagle (RGE), and Marubeni Corporation. 
Figure 4. Crude Palm Oil Mills in Central Sumatra 2017, Investigated CPO Mills on Illegal Fresh Fruit Bunch (FFB) Purchase, and Plantation Status

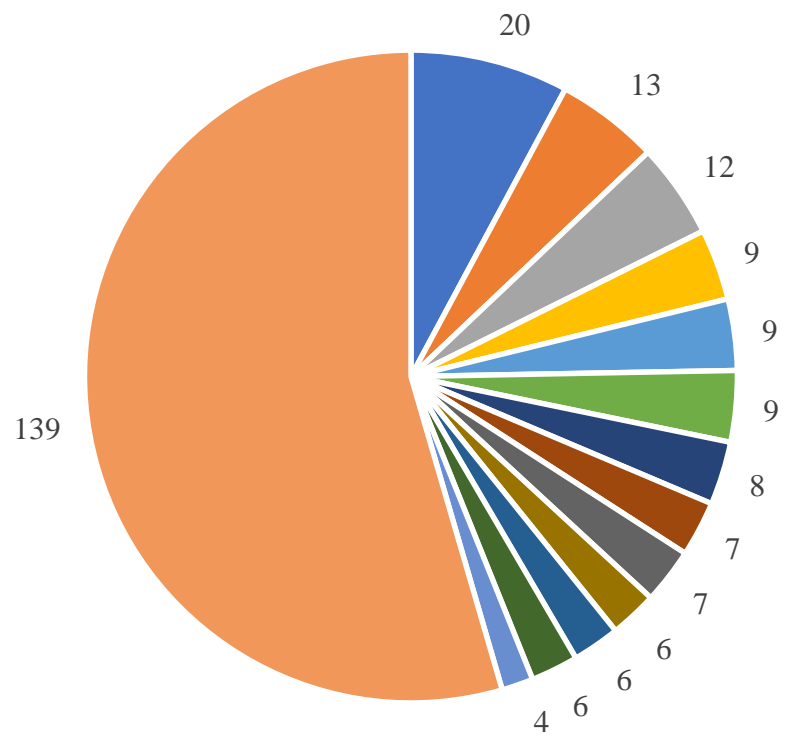

- PTPN

- Sinarmas

- $\mathrm{RGE}$

- Astra

- Darmex

- First Resources

- Indofood

- Wilmar

- Gama

- Musim Mas

- TH Plantation Berhard

- Sime Darby

- Sarimas

Investigated CPO Mills on Illegal FFB Purchase

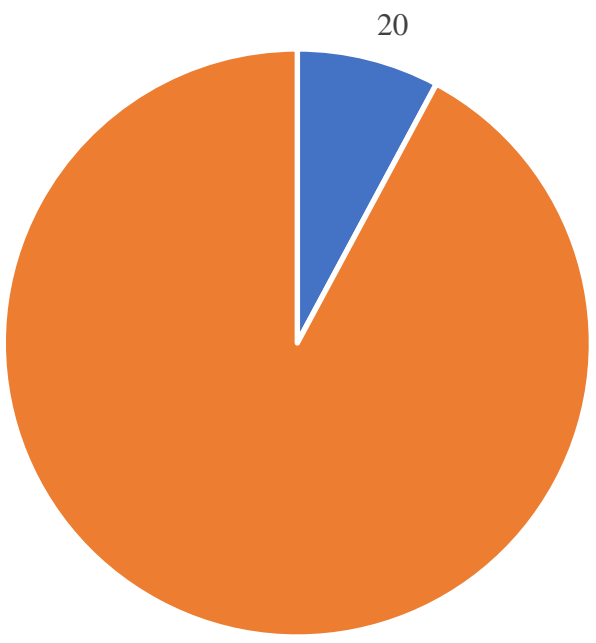

- Illegal FFB

- Not Investigated/Found 


\section{Plantation Status}

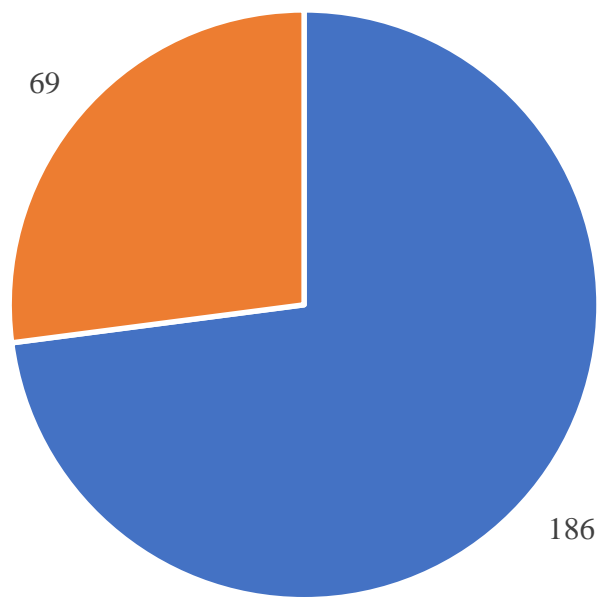

- Own

- Independent

Source: Abstracted from Eyes on the Forest, 2018, "Sumatra's Forests, their Wildlife, and the Climate Online Database", accessed from http://maps.eyesontheforest.or.id/ on October 10, 2018; Ministry of Forestry, Peta Indikatif Arahan Pemanfaatan Hutan pada Kawasan Hutan Produksi yang Tidak dibebani Izin untuk Usaha Pemanfaatan Hasil Hutan Kayu (Jakarta: Kementerian Kehutanan, 2014); Ministry of Forestry, Buku Basis Data Spasial Kehutanan 2013 (Jakarta: Kementerian Kehutanan, 2013); Ministry of Forestry, Buku Basis Data Spasial Kehutanan 2014 (Jakarta: Kementerian Kehutanan, 2014)

Figure 4 has abstracted data based on Eyes on the Forest publication which has mapped 256 (or 255) Crude Palm Oil (CPO) mills in Central Sumatra, particularly in Riau and Jambi Provinces - the epicenter of palm oil production in the world. Many are connected to some of the largest palm oil producers in the world. Much of the CPO produced by the mills is trucked to refineries which deliver their products to Indonesia's domestic market and around the world (Eyes on the Forest, 2018). Many of the CPO mills have no plantations of their own ("independent", see Figure 4 above) and rely on third party deliveries of Fresh Fruit Bunch (FFB). No mechanisms appear to be in place to verify whether that FFB was grown legally. Random investigations by WWFIndonesia and Eyes of the Forest found $20 \mathrm{CPO}$ mills to have received illegal FFB from Tesso Nilo complex, Bukit Batabuh Tiger Corridor (BBTC), or the adjacent Forest Areas between 2011 and 2017. Deforestation also occurred in those areas as shown in Figure 5 below. 
Figure 5. Deforestation History in Five Investigated Areas (Tesso Nilo National Park, PT. Hutani Sola Lestari, PT. Siak Raya Timber, Bukit Batabuh Tiger Corridor, and PT. Dalek Hutani Esa)

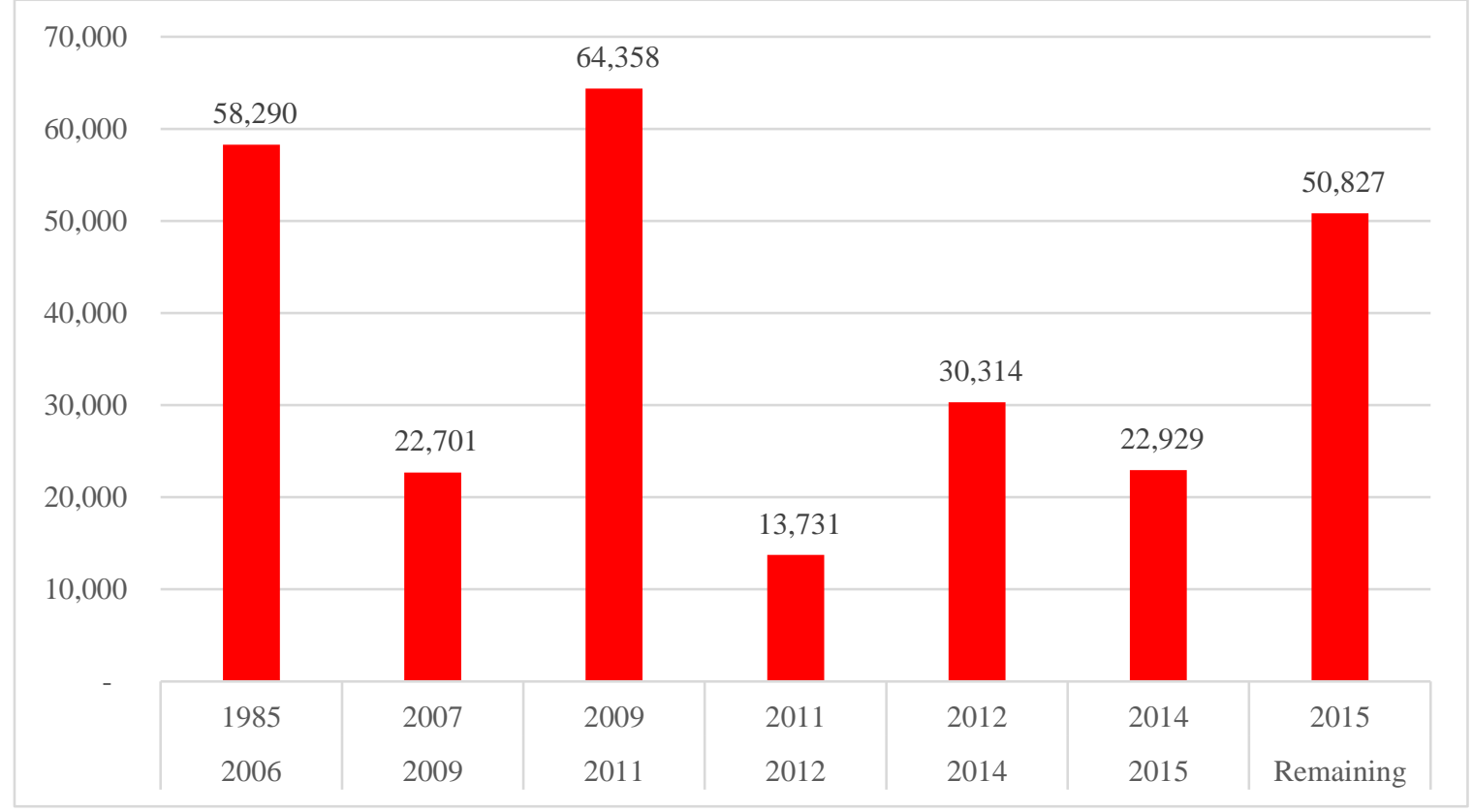

Source: Abstracted from Eyes on the Forest, "Sumatra's Forests, their Wildlife, and the Climate Online Database", accessed from http://maps.eyesontheforest.or.id/ on October 10, 2018; WWF Indonesia, Palming off a National Park: Tracking Illegal Oil Palm Fruit in Riau, Sumatra (Jakarta: WWF Indonesia, 2013)

Figure 5 shows deforestation occurred in several forbidden and protected areas. These areas have been important remaining natural habitat for critically endangered Sumatran elephants and tigers. Illegal deforestations for oil palm have broken the link. Illegal plantations have forced those protected species to travel through oil palm plantations where they are often threatened by plantation managers and poachers. These threats could trigger conflict with local societies.

Discussing Tesso Nilo National Park, we can find a number of illegal plantations as shown in Figure 6. 
Figure 6. Illegal Plantations in Tesso Nilo National Park 2017

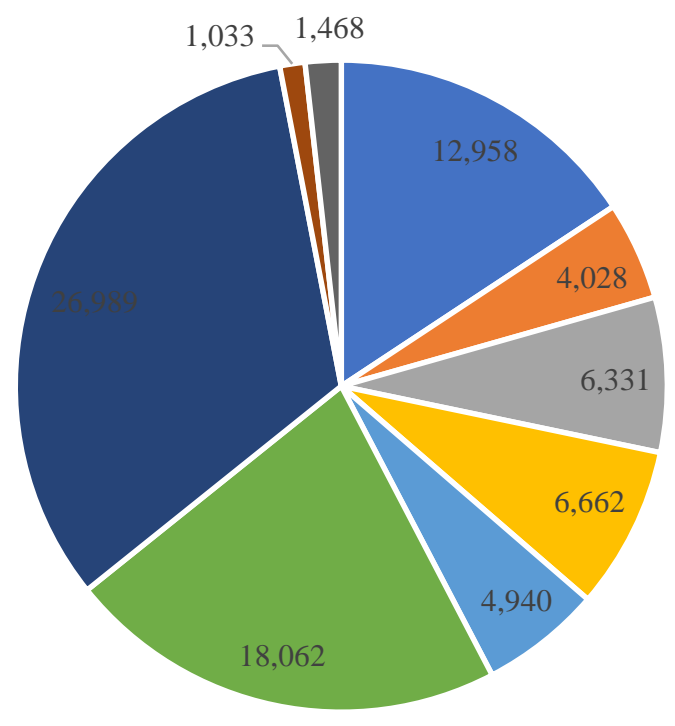

- Natural Forest

- Pulpwood Plantation

- Oil Palm >= 5 Years Old

- Oil Palm <= 5 Years Old

- Oil Palm Unverified

- Mixed Plantation

- Cleared Area with Vegetation

- Cleared Area

- Other

Source: Abstracted from Eyes on the Forest, 2018, "Sumatra's Forests, their Wildlife, and the Climate Online Database", accessed from http://maps.eyesontheforest.or.id/ on October 10, 2018

There are at least three compulsory discussions on Indonesia haze-free agenda especially in Riau Province, specifically the governance on (1) palm oil plantation, (2) peatlands, (3) Licensed Logging Concessions (Hak Pengusahaan Hutan; HPH) and Industrial Timber Estates or Pulpwood (Hutan Tanaman Industri; HTI), and (4) disaster management regarding fire spots and haze.

\section{CSOs PERSPECTIVES ON ASEAN HAZE-FREE AGENDA}

In the midst of an idea narrative contestation in mitigating peatland fires in Riau province, the researchers are trying to get some perspectives on disaster mitigation efforts from several CSOs in Riau. Several debates arose over the CSOs - ranging from the term "agents of foreign interests" to the issue of intervention into state sovereignty (Djailani, 2016; Merdekakan; 2016; Baihaqi, 2017). It is widely understood that any criticism by CSOs against Indonesian palm oil industry governance is a threat to Indonesian economy, backed by foreign interests (Hasan, 2017; Amri, 2017, Sudarsono, 2018). This perception towards CSOs surged as government officials, academic and even analysts believe that many CSOs receive foreign funding and run foreign agenda setting, namely trade war (Djailani, 2016, Baihaqi, 2018; Sudarsono, 2018). The CSOs' campaign against Indonesia's Palm Oil governance is seen as a black campaign against one of Indonesia's core export products (Djailani, 2016; Baihaqi, 2018) which may provide advantage to European sources of vegetable oils, particularly soybean and rapeseed (Roda, 2019). However, it is observed that in this field, the CSOs seek to work in their own way, and in the midst of all the criticisms towards their independence and neutrality, they keep campaigning against improper and unsustainable plantation practices that damage the 
environment, with their campaigns ranging from socialisation to advocating this problem to legal institutions. These have led the researchers to further examine the perspectives that can be given by CSOs in Riau. In this study, the researchers managed to gather perspectives from CSOs in Riau such as: Walhi, Jikalahari, FITRA, and the Center for Disaster Study at the University of Riau.

\section{Walhi Riau}

According to Riko Kurniawan (Walhi Riau Regional Executive), in handling forest fires, there should no longer be discussions about the fire, but instead, the peatlands (Kurniawan, 2018). The uniqueness of the peat which is located on the coast of Sumatra is different from peats in other parts of the world. The peat on the coast of Sumatra is moist, and local wisdom has been able to manage the peat well. For example, some tribes in Riau Province, Talang Mamak, Petalangan, and Sakai were able to solve the issue (Kurniawan, 2018).

Examining the government's perspective in looking at forest fire disasters from 2015 until 2018, the accumulation made by the government in calculating peatlands is not appropriate. The government often equates the mitigation of this disaster by looking at the land in Riau as a land that contains minerals rather than peat, whereas peatlands are different from minerals. Thus, the orientation of the government is only on fire extinguishing process.

Table 2. Distribution of Fires in Peatlands vs. Mineral and Distribution in Concessions

\begin{tabular}{cccccccccc}
\hline \multirow{2}{*}{ Distribution of Fires } & \multirow{2}{*}{ Total } & \multicolumn{2}{c}{ Mineral } & \multicolumn{7}{c}{ Peatland } \\
\cline { 3 - 10 } & & $\#$ & $\%$ & $\#$ & $\%$ & HPH & HTI & HGU & Etc \\
\hline $\mathbf{2 0 1 0}$ & 4,117 & 1,131 & 27.47 & 2,986 & 72.53 & 65 & 1,471 & 751 & 699 \\
\hline $\mathbf{2 0 1 1}$ & 6,624 & 2,020 & 30.50 & 4,604 & 69.50 & 142 & 2,476 & 1,354 & 632 \\
\hline $\mathbf{2 0 1 2}$ & 7,840 & 3,134 & 39.97 & 4,706 & 60.03 & 224 & 3,121 & 1,487 & $(126)$ \\
\hline $\mathbf{2 0 1 3}$ & 15,059 & 4,142 & 27.51 & 10,917 & 72.49 & 337 & 5,327 & 2,974 & 2,279 \\
\hline $\mathbf{2 0 1 4}$ & 20,827 & 1,960 & 9.41 & 18,867 & 90.59 & 349 & 9,126 & 3,668 & 5,724 \\
\hline
\end{tabular}

Source: Abstracted from data analysis on Focus Group Discussion, CSOs Perspective

Regarding ASEAN Haze-free 2020. Universitas Abdurrab, Pekanbaru, Riau. October 02, 2018.

Riko Kurniawan also talked about the comparison of hotspots with local and national political situations. Political relations with the number of hotspots in Riau can be calculated when the number of hotspots coincides with the regional general elections (Kurniawan, 2018). Usually, the government of the day would use this to appease the hearts of the people, especially for incumbent candidates. Besides that, the existence of hotspots with politics can be correlated with the very expensive political costs in Riau, making human resource a source of funds, especially as palm oil is one of the many plantations associated with the emergence of smoke disasters as extractive industries in the Republic of Indonesia.

The economic reason for private companies in clearing land by burning is to eliminate high acid levels in Riau's peatlands. The act of draining peatlands by burning 
and building canals is believed to be a way which is able to eliminate acid levels. There are clear rules and legal basis for compliance by forest concession owners in Riau. However, the implementation of regulations and the legal basis is too centralistic, so much so, that the government is often ignorant as to what actually takes place at the supervisory level. As an example of the regulation on land ownership in Riau, from a total of 3.4 million hectares of forest concessions in Riau, 1.8 million hectares of land has not been granted release permits (Kurniawan, 2018). It also propagates to regulations concerning the management of fire suppression owned by concessions, for example, the existence of a fire control tower in the field and the provision for ownership of fire fighting machines per hectare. A compliance audit on all these conditions which was carried out in 2014 proved that all concessions in Riau were not compliant. Supervision should be carried out every 6 months, but the government is always constrained by budget and human resources.

Table 3. Licensing Distribution in Peatlands based on Depth

\begin{tabular}{cccc}
\hline Licensing Distribution in Peatlands & HPH (Ha) & HTI (Ha) & Sawit (Ha) \\
\hline $\mathbf{5 0}$ & & $1,038.12$ & $30,697.48$ \\
\hline $\mathbf{5 0 - 1 0 0}$ & 172.35 & $47,613.96$ & $111,901.68$ \\
\hline $\mathbf{1 0 0 - 2 0 0}$ & $31,931.22$ & $206,261.74$ & $244,532.66$ \\
\hline $\mathbf{2 0 0 - 4 0 0}$ & $2,319.54$ & $276,625.71$ & $271,176.82$ \\
\hline$>\mathbf{4 0 0}$ & $141,388.96$ & $731,053.76$ & $162,109.47$ \\
\hline Total & $\mathbf{1 7 5 , 8 1 2 . 0 7}$ & $\mathbf{1 , 2 6 2 , 5 9 3 . 2 9}$ & $\mathbf{8 2 0 , 4 1 8 . 1 1}$
\end{tabular}

Source: Abstracted from data analysis on Focus Group Discussion, Civil Society Perspective Regarding ASEAN Haze-free 2020. Universitas Abdurrab, Pekanbaru, Riau. October 02, 2018.

Forest mismanagement in Riau is caused by the domination of extractive industries supported by the government. This can be seen from the permits that are usually granted by the local government to corporations for opening up oil palm land in Riau. However, the government often puts the blame on small-scale farmers and private landowners for the land mismanagement that leads to forest and land fires, whereas in reality, these corporations are the ones able to perform land-clearing massively.

The thing that makes a long history of forest mismanagement in Riau is the miscalculations made by the government. The government usually calculates all land planted with oil palm in Riau Province, including private land owned by the society, thus, when a land fire occurs, people are often blamed, even though 3.4 million hectares of land in Riau is controlled by corporations. Licensing distribution provided by the government tends to be oriented towards extractive industries, so the government usually gives permission to corporations to open land.

The Walhi (Kuniawan, 2018) demands consist of:

1. The finding that the government is still focusing on the process of "extinguishing fire", and not on disaster mitigation, whereas 1.8 million hectares of oil palm land 
in Riau province is in the forest area. Government must focus on disaster mitigation by unraveling and overcoming the roots of the problem.

2. Conduct audit and revision of all agreements on peatlands,

3. Law Enforcement (one door policy; lex specialis cases) including the administrative checking process by security forces, judges, prosecutors, police in one perspective (environment).

4. Make a One Map Policy; create a transparancy map of recorded forest fires.

5. Moratorium on clearing of natural forests and peatlands.

6. Palm and mining moratorium.

7. Peatland rehabilitation and restoration (Badan Restorasi Gambut clauses).

8. Increasing the allocation of community management space.

9. Making preventive control measures; one of the qualified society groups known as "Masyarakat Peduli Api".

10. Making a community evacuation protocol; one of them is Early Warning System

\section{Jikalahari}

The efforts of the Riau provincial government in mitigating smoke disasters are still constrained in the law enforcement process, according to Yaya, one of the representatives of Jikalahari Riau, which is one of the CSOs focusing on environmental issues. There are 49 corporations suspected of burning land in Riau during the period of $2014-2016$ (Yaya, 2018). As a result of protracted legal proceedings, post-disaster handling has never been carried out. Charges of civil violations were filed against corporations involved, while charges of criminal violations were filed against individuals who were responsible for the process of land clearing. Due to the slowness of the legal process on this issue, Riau residents who are members of the "Koalisi Rakyat Riau" also made demands based on the missing link between legal cases experienced by several corporations in Riau.

The missing link is caused by differences in the judges' perspectives in seeing environmental issues. The prosecutor in court always consider that there has been a handling or management of this problem, but it is not optimal, even though there is a Standard Operational Procedure (SOP) already in place. Too much is compromised. In this case, the society is always blamed, even though it is clear that there are laws that can ensnare concessions on this issue. In addition, the fire is said to occur due to the negligence of the corporations in completing the SOP and accidents, as there is no government supervision (Yaya, 2018). 
Picture 4. 49 Corporations in Riau Suspected of Causing Peatland and Forest Fires

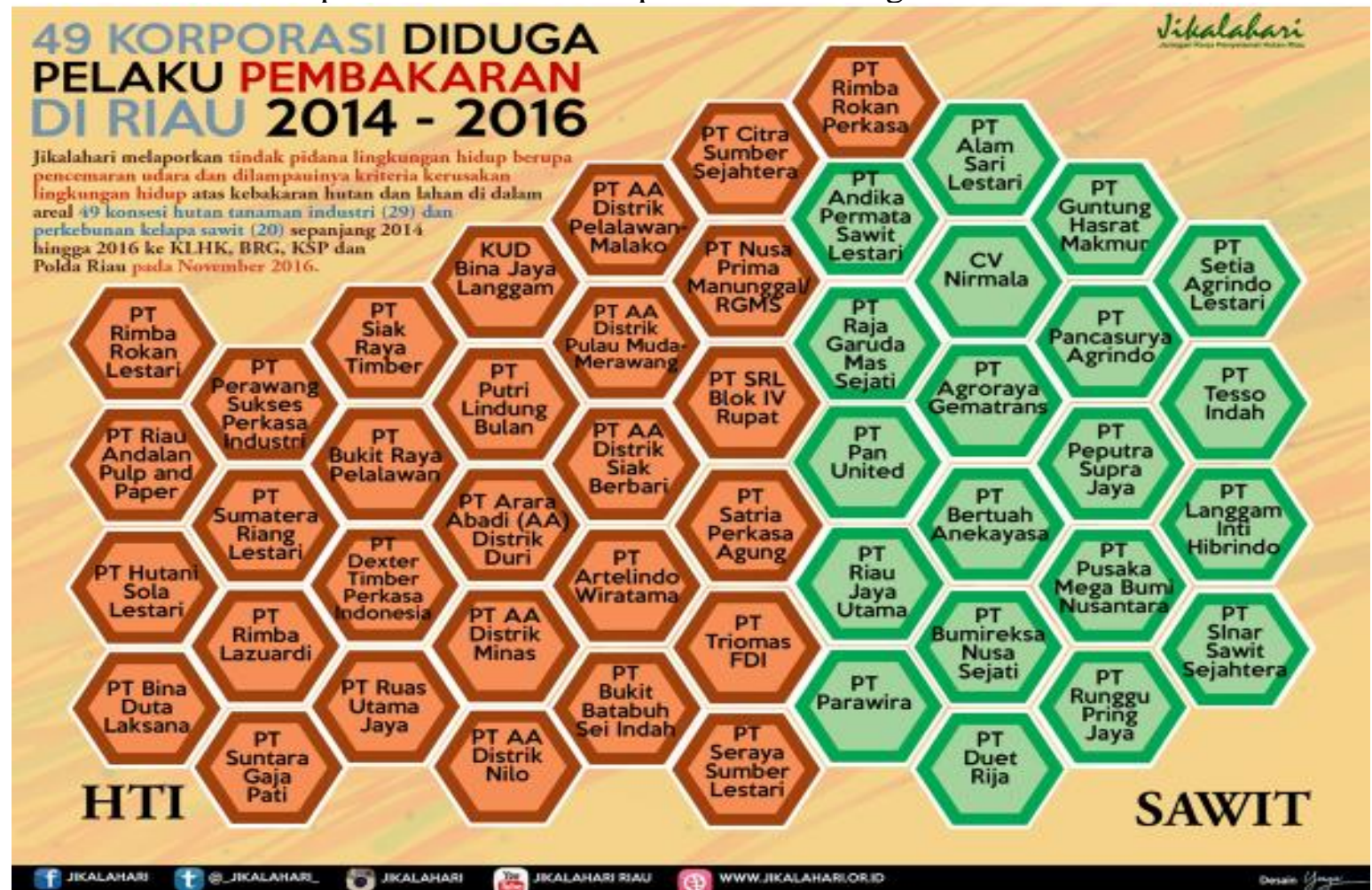

Source: Jikalahari on Focus Group Discussion, CSOs Perspective Regarding ASEAN

Haze-free 2020. Universitas Abdurrab, Pekanbaru, Riau. October 02, 2018.

Hotspot trends also relate to law enforcement. In 2005, illegal logging activities became massive. This was alleged by 14 corporations that indicated bribery against the regent (Bupati) of Siak and Pelalawan at that time. Land clearing by burning of natural forest that was part of pulpwood was conducted again in order for this area to be replanted with oil palm.

\section{FITRA Riau}

FITRA as a CSO focuses on observing budget policy and transparency, and highlights that there is a significant reduction in the budget in efforts to mitigate smoke disasters in Riau. In 2018, Riau only spent USD6.8 billion, down around 77\% from USD29 billion in 2017 (Fitra Representative, 2018). In addition, the issue of transparency in the Environmental Impact Analysis (Amdal in Indonesia) in Riau is also still very difficult to access. Some information from the government and corporations that should be accessible to the public is still difficult to obtain. This has an impact on people living in rural areas, far from the capital city.

Overlapping is also one of the obstacles to handling smoke disasters in Riau province. The implementation of haze disaster mitigation in Riau is carried out by the provincial government, but in initiating "Hak Guna Usaha" permited by the district government, so this overlap results in many commitments that are only signed on the 
table, but the implementation is very far from the expectation. As a result, the provincial government only focuses on the budget on the fire extinguishing process, so that if the extinguishing is lacking then the budget is reduced.

\section{Riau Center for Disaster Studies (Pusat Studi Bencana Universitas Riau)}

According to Zailany, a volunteer at the University of Riau Disaster Center (Pusat Studi Bencana), forest management system based on the rules was expensive, thus burning it became more economical. In the field, there are also disputes over land ownership whether it is privately-owned or if it is a corporate land, as there are cases whereby even though the size of the land is 100 hectares, it is owned and held on behalf of individuals (Zailany, 2018).

The characteristics of peatlands in Riau are also interesting. The findings in the field show that fires on peatlands cannot be extinguished by conventional methods, but special efforts must be made, such as applying injections to burned land. Government efforts to create programs in the forms of socialisation and persuasion efforts are also constrained by the length of the administration of, and training for the community. Usually, the community enters into a volunteer program such as, "Masyarakat Peduli Api". However, when it comes to its implementation in the field, the lack of coordination between the people and related stakeholders also leads to the problem of overlapping activities. This is coupled with the general perspective of developing countries that disaster mitigation funds can be used as a profitable project (Zailany, 2018).

From the above presentation of the perspectives of the four CSOs, it can be concluded that there are three important areas that must be improved with respect to mitigating forest fires in Riau province. First, the difference between the perspectives of the legal and corporate apparatus leads to less coordination and synergy, and sometimes even tends to be compromised. Second, an ineffective policy due to lack of coordination and transparency causes very minimum, if not zero, implementation. Third, government's attention is only focused on fire extinguishing, with the idea that the budget can be reduced if the extinguishing process is also reduced. This effectively means that pre and post disaster mitigation efforts are still far from being implemented.

\section{FROM DEMAND TO SUPPORT: BRIDGING THE MULTI ASPECT COLLABORATION}

There are still some problems with regard to the haze and haze-related issues.

The first problem is that there are still fire spots and illegal plantation based on the maps that were shown before (see Picture 1).

Second, besides environmental and disaster matters, Indonesia is still facing productivity problems on the CPO industry. Before 2018, according to data acquired from Indonesia's Statistics Agency (BPS), the total area of oil palm plantations in Indonesia was around 11.9 million hectares; a figure that was about three times higher 
than in the year 2000 when around four million hectares of Indonesian soil was used for oil palm plantations. This figure is estimated to increase to 13 million hectares by the year 2020 (BPS, 2017). The latest data from the Ministry of Agriculture confirmed that the current total area of oil palm plantations in Indonesia is around 14.03 million hectares, bigger than it was predicted before (KOMPAS, February 26, 2018).

Table 4 below, provides an interesting comparison between Indonesia and Malaysia. It shows that Indonesia's oil palm planted area is around 14.03 million hectares, while Malaysia has around 5.74 million hectares. By these planted area, Indonesia's national annual yield on palm oil is 17 tons per hectare with $46 \%$ matured plantation, while Malaysia has a much bigger yield at around 21 tons per hectare with $86 \%$ matured plantation. In terms of quantity, Indonesia is much bigger and productive than Malaysia, but, in some important contexts, Malaysia's palm oil production and plantation qualities are more productive than Indonesia's. One of the most important factors is the aspect of technology-driven plantation. Therefore, Indonesia should facilitate and actuate the science and research-based policy on palm oil plantation and production. More focus must be aimed at intensification, rather than expansion programmes, as this is the most strategic and the exact policy for Indonesia to adopt considering her prevailing situations and conditions (Tyson A, Varkkey H, Choiruzzad $\mathrm{SAB}, 2018)$.

Table 4. Indonesia and Malaysia Productivity and Efficiency Comparison 2018

\begin{tabular}{lcc}
\hline Variables & Indonesia & Malaysia \\
\hline Production Capacity (MT) & $6,688,788$ & $3,599,780$ \\
\hline Production Area (Ha) & $8,000,000$ & $4,888,756$ \\
\hline Production (1k MT) & 40,500 & 21,000 \\
\hline Export (1k MT) & 29,500 & 17,900 \\
\hline Domestic Consumption (1k MT) & 10,130 & 3,425 \\
\hline Planted Area (Mn Ha) & 14.03 & 5.74 \\
\hline National Anuual Yield (T/Ha) & 17 & 21 \\
\hline Oil Extraction Rate (\%) & - & 20 \\
\hline World Market Share & 46 & 41 \\
\hline Mature (\%) & 75 & 86 \\
\hline Immature (\%) & 25 & 14 \\
\hline Trade Value (US\$) & $18,513,121,264$ & $9,659,648,524$ \\
\hline
\end{tabular}

Source: Abstracted from Index Mundi, Palm Oil Database, accessed from https://www.indexmundi.com/agriculture/?commodity=palm-oil\&graph=exports, "Kementerian Pertanian: Lahan Sawit Indonesia Capai 14,03 Juta Hektare", KOMPAS, February 26, 2018

https://ekonomi.kompas.com/read/2018/02/26/203000426/kementerian-pertanian--lahansawit-indonesia-capai-14-03-juta-hektare, Ahmad Khusairi Din, Malaysian Palm Oil Industry Performance 2016 and Prospect for 2017 (Kuala Lumpur: Pullman Kuala Lumpur City Centre, 2017); Tyson A, Varkkey H, Choiruzzad SAB, 2018. 
Third, there was an unnecessary legal-political confrontation with the Indonesian President when the Indonesia Palangkaraya High Court decision resolved that President Joko Widodo (Jokowi), four of his cabinet ministers and the local administration were accountable for causing the Indonesia haze disaster in Central Kalimantan in 2015 (Ihsanuddin, 2018; Pahlevi \& Widyastuti 2018; Saputra, 2018). Although the court decision was pertaining to haze issues in Kalimantan, it definitely has a nationwide impact, and in particular, very relevant to Riau Province. It is important to note that the environment sector is a joint-responsibility affair between the national/central government and local governments. Thus, decisions by the national government on the environmental sector will provide significant impacts on local policies. The President however, had challenged the decision and appealed to the Indonesia Supreme Court and proposed cassation of the judgement (KOMPAS, August 23, 2018). ${ }^{1}$

We see that there was a political game that could not be politically capitalized by the President. His administration should have accepted the citizen lawsuit that was proposed by WALHI as that was the key solution for Indonesia haze-free agenda and haze-related disaster management. All this time, Indonesia has always been confronted with the "no legal protection" issues. The citizen lawsuit that could, and would be the legal protection itself, however, was rejected by the President. There was a political game that was lost by the President of Indonesia. If President Jokowi had accepted the lawsuit, this would be beneficial for Indonesia's sustainable development governance and also for the President's political achievements because this haze problem is seen as a "hereditary" problem from previous administrations (from President Soeharto to President Soesilo Bambang Yudhoyono: 6 previous Presidents). If this step was taken, President Jokowi could have gained a huge political mileage by stating that only during his administration that the sustainable development governance, or specifically environmental governance, is set as a priority agenda. However, the complicated political situation of the day had led to Jokowi's administration choosing to reject the lawsuit. This, the researchers see, is a loss for Indonesia's sustainable development governance, and for President Jokowi's political achievement.

It is true from the perspective of law that President Jokowi, as the Head of Government, had the right to refuse the court decision by submitting the appeal for cassation to the Supreme Court. However, this had been portrayed as a defensive gesture which indicated that the government was trying to avoid responsibility. Political ego had preceded national and regional interests. By these understandings, haze then potentially becomes a political commodity. Haze will potentially be politicized as a matter of political gains during election cycles. During the presidential candidate debate which took place in February 2019, President Joko Widodo claimed that there was no more forest fires and peatland fires. The incumbent presidential candidate number 01, Joko Widodo, stated that the government he led had succeeded in overcoming forest and land fires in the past three years. He stated during the debate that, "In the environment, peatland fires do not occur, and we can overcome this. In three years, there have been no fires, forests (or) peatland fires. It is all our hard work," (Kompas, 17/2/2019). In less than twenty-four hours, strong criticisms emerged from the public, starting with academics, NGOs, civil society organizations and politicians (RMOL, 17/2/2019). The 
day after, President Joko Widodo, through the National Campaign Team, then corrected his statement, "Jokowi admitted that in the past three years there were still forest and land fires, but the number had dropped significantly. That is, not (that there was) none (forest fires), but, (the number) has dropped dramatically, down 85 percent more" (Kompas, $18 / 2 / 2019)$.

The recent updates on this case, on 16 July 2019, the Indonesian Supreme Court rejected President Jokowi's application for cassation and he was found guilty with his four ministers: Environment and Forestry Minister; Health Minister; Agrarian and Spatial Planning Minister; Agriculture Minister, Central Kalimantan Governor and Central Kalimantan Provincial Members of Parliament in 2015 (Perlawanan 2019; Tio \& Daryono 2019; Mahkamah, 2019; Ramadhan, 2019). In response to this, the President will seek the last resort to challenge this decision by filing a case review (Indonesian, 2019; Mahkamah 2019). Walhi activists consider the President's effort to conduct a case review as "a useless action and a betrayal" towards its own regulations (Presidential Instruction Number 11) which has been issued with regard to the increasing control of land and forest fires (PK Jokowi, 2019). Should the case review brought by President Jokowi prove to be successful, the decision will surely mark a negative sign to the future of haze-free ASEAN region and sustainable development efforts in Indonesia.

Overall, CSOs' views regarding the haze and haze-related issues have a great deal in common, the main one being that the government put too much attention on extinguishing the fires, while the root causes of the problem were neglected. Haze is only a tip of the iceberg from the problem of sustainable development in the environmental sector. The problem of haze will lead us to many more problems of sustainable development that have not been addressed yet. There are problems with peat governance, water management and water sharing governance, swamp governance, and the environmental governance.

Based on FGDs and interviews that have been held and carried out, we established some findings and stated several thesis statements. Based on David Easton's theory, ASEAN haze-free agenda in Riau Province cannot significantly ameliorate the haze-free governance in Riau. Some policies which were part of the output on haze-free policies in Riau had culminated in new problems. The problems were caused by too much demand, rather than the support aspects that have been addressed by CSOs in Riau Province. The support aspect had been under-discussed in the haze discourse in Indonesia, especially in the Riau Province. The support that we are discussing here essentially comes from academic works and political representatives which are not properly organized and connected within Indonesia's political systems. What we mean by support is not merely an administrative matter, but also strategic supports which are related to policy intervention as the outcome. Strategic supports need synergy and collaboration between academics, politicians, business sectors, and influential individuals or philanthropies, and CSOs to not just look at the demand aspect. 


\section{CONCLUSION}

Based on the explanation and analysis made from the application of David Easton's theory, we analyse that there is an imbalance between demand and support as inputs towards the political system and decision-making process in Riau Government. The imbalance between these two has created complex and complicated relations between environmental CSOs and Riau Government. The environmental and haze-free agendas in Riau have relied too much on demand as the input for decision-making process, particularly by observing CSOs agenda. We see that the support aspect is also important and mandatory in addressing this situation. Our main argument on multi aspect collaboration is that it requires an agenda which is based on a balanced role of providing both demand and support aspects by actors from CSOs and other various sectors. These sectors include academics, businesses, individuals, and mainstream media. This supportbased decision-making process requires the centrality of Riau Province Government as the anchor. This collaborative work has to open doors to transboundary collaboration involving actors from the above-mentioned sectors from neighbouring South-East Asian countries. This collaborative work is not only about various formal administrative and ceremonial activities such as publications, workshops, seminars and talks per se. Instead, we are expecting more significant efforts and social impact in the forms of policy intervention and policy implementation.

By these considerations, we propose three related strategic programmes to support the haze-free agenda for a long term strategic solution:

1. ABC-GIM Collaboration: Socialisation, Empowerment, and Campaign. We find the urgency of collaboration between Academics, Businesses, Civil Society Organizations, Governments, Individuals, and the Media (ABC-GIM) to conduct research and analysis as well as voluntary good actions on haze-free agenda and some related strategic issues including economy, politics, social and nontraditional (human) security.

2. From Expansion to Intensification: Science and Research-based Policy. We find that oil palm plantations have met its end line. We need to focus more on oil palm land intensification than expansion. This has economic advantages as well as embracing aspects of environmentalism. Science and Research-based Policy would be necessary to be included in the Haze-free agenda. There are many researches on palm oil land intensifications that could support the agenda.

3. Transboundary Collaboration: Harnessing the ASEAN Way. Based on ASEAN Haze-free commitment, we must address the 'ASEAN Way' as platform to build a regional multi-aspect collaboration between Academics, Businesses, Civil Society Organizations, Governments, Individuals, and the Media (ABCGIM). If ASEAN countries, especially Indonesia, Malaysia, and Singapore, propel and actuate every ABC-GIM sectors in their countries to collaborate, these 
kinds of regional support would become the strategic drives for ASEAN Hazefree agenda.

Meanwhile, for short-term solution, the local-Riau government administration (with the help of the national government) must ensure that law enforcement regarding the haze issue and fire extinguishing efforts are upheld in the first instance.

\section{NOTES}

${ }^{1}$ Based on the decision, the President was sentenced to issue implementing regulations from Law Number 32 of 2009 concerning Environmental Protection and Management, which are important for the prevention and control of forest and land fires, by involving community participation, in the form of seven government regulations. The seven government regulations are Presidential Regulation concerning procedures for determining the carrying capacity and carrying capacity of the environment; Presidential Regulation concerning environmental quality standards; Presidential Regulation concerning standard criteria for environmental damage related to forest and/or land fires; Presidential Regulation concerning environmental economic instruments; Presidential Regulation concerning environmental risk analysis; Presidential Regulation concerning procedures for handling environmental pollution and/or damage; and Presidential Regulation concerning procedures for restoring environmental functions. In addition, the President was also sentenced to issue government regulations or presidential regulations which became the legal basis for the formation of a joint team to prevent and overcome forest and land fires. The government decided to appeal to the Supreme Court.

\section{REFERENCES}

Ahmad Khusairi Din, Malaysian Palm Oil Industry Performance 2016 and Prospect for 2017 (Kuala Lumpur: Pullman Kuala Lumpur City Centre, 2017)

Akbar, Wishnugroho: "Beredar Foto Polisi Pesta Dengan Bos Sawit", (2016, September 9) retrieved from <https://www.cnnindonesia.com/nasional/20160903121118-20155865/beredar-foto-polisi-pesta-dengan-bos-sawit-riau>, [accessed June 2019]

Akuntono, Indra. (2016). Mensos: 19 orang meninggal karena kabut asap. Accessed from:

https://nasional.kompas.com/read/2015/10/28/11514061/Mensos.19.Orang.Menin ggal.karena.Kabut.Asap on 6 October 2010

Alfajir \& Luerdi. (2016), "Riau Government's Policies to Realize the AATHP Goals 2015-2016)", Prosiding seminar hasil penelitian Universitas Abdurrab, Pekanbaru, ISBN 978-602-61188-1-3

Amri, Qayuum: "Ada kepentingan negara barat dibalik kampanye hitam sawit", December, 11 2017, <https://sawitindonesia.com/ada-kepentingan-negara-baratdibalik-kampanye-hitam-sawit/>, [accessed, July 2019]

Aw, Tash (2015). Southeast Asia’s Hazy Future. Accessed from https://www.nytimes.com/2015/10/02/opinion/tash-aw-southeast-asias-hazyfuture.html on 6 October 2018

Baihaqi, Muhammad Bari: "Kampanye hitam sawit dianggap sebagai persaingan dagang", October, 11 2018, <https://www.neraca.co.id/article/107497/kampanyehitam-sawit-dianggap-sebagai-persaingan-dagang>, [accessed, July 2019] 
"Bantah Jokowi, Greenpeace: Kebakaran Hutan Terus Terjadi Setiap Tahun", February, $172019, \quad<$ https://politik.rmol.co/read/2019/02/17/378988/bantah-jokowigreenpeace-kebakaran-hutan-terus-terjadi-setiap-tahun>, [accessed, May, 1 2019]

Carbon Dioxide Information Analysis Center, Environmental Sciences Division, Oak Ridge National Laboratory, Tennessee, United States; World Bank Open Data, $\mathrm{CO} 2$ Emissions (kt), accessed from https://data.worldbank.org/indicator/EN.ATM.CO2E.KT

"Cek Fakta: Jokowi Klaim Tak Ada Kebakaran Hutan dan Lahan 3 Tahun Terakhir", February, 17 2019, <https://ekonomi.kompas.com/read/2019/02/17/210507526/cek-fakta-jokowiklaim-tak-ada-kebakaran-hutan-dan-lahan-3-tahun-terakhir>, [accessed, May, 1 2019]

Djailani, M Fadil: "DPR soroti dana hibah masuk kas 1sm lingkungan", February, 12 2016, <https://ekonomi.inilah.com/read/detail/2273712/dpr-soroti-dana-hibahmasuk-kas-lsm-lingkungan>, [accessed, July 2019]

"Divonis Bersalah atas Bencana Asap, Ini Komentar Presiden Jokowi", KOMPAS, August 23, 2018, accessed from https://nasional.kompas.com/read/2018/08/23/13432791/divonis-bersalah-atasbencana-asap-ini-komentar-presiden-jokowi

Emisi Karbon dari Gas Kebakaran Hutan RI Melebihi Amerika, 19 Oktober 2015, accessed from https://nasional.tempo.co/read/710972/emisi-karbon-dari-gaskebakaran-hutan-ri-melebihi-amerika/full\&view=ok [accessed, 6 October 2018]

Easton, David., 'Analisis Sistem Politik' [Political System Analysis]., in Perbandingan Sistem Politik [Comparative Politics], ed. Mas'oed, Mohtar and Collin MacAndrews (Gajah Mada University Press, Yogyakarta, 2008)

Erdianto, Kristian: "Wakapolri: SP3 Kebakaran Hutan di Riau tak Terkait Foto Kongko Perwira Polri-Pengusaha", September, 13 2016, <https://nasional.kompas.com/read/2016/09/13/15443181/wakapolri.sp3.kebakara n.hutan.di.riau.tak.terkait.foto.kongko.perwira.polri-pengusaha>, [accessed, June 2019]

Eyes on the Forest, "Sumatra's Forests, their Wildlife, and the Climate Online Database", accessed from http://maps.eyesontheforest.or.id/ on October 10, 2018; original data is available in NASA, Earth Data on Active Fire Data, accessed from https://earthdata.nasa.gov/earth-observation-data/near-real-time/firms/active-firedata\#tab-content-6 on October 11, 2018.

Eyes on the Forest, "Sumatra's Forests, their Wildlife, and the Climate Online Database", accessed from http://maps.eyesontheforest.or.id/ on October 10, 2018

Eyes on the Forest, 2018, "Sumatra's Forests, their Wildlife, and the Climate Online Database", accessed from http://maps.eyesontheforest.or.id/ on October 10, 2018.

Fahmi, Khairul: "Jokowi, Asap dan Kerusakan Lingkungan", September, 16 2015, <https://geotimes.co.id/kolom/jokowi-asap-dan-kerusakan-lingkungan/>, [accessed, May 2019]

Focuss Group Discussion, Civil Society Perspective Regarding ASEAN Haze-free 2020. Universitas Abdurrab, Pekanbaru, Riau. October 02, 2018. 
Forsyth, T. (2014) 'Public concerns about transboundary haze: a comparison of Indonesia, Singapore, and Malaysia'. doi: 10.1016/j.gloenvcha.2014.01.013.

Hardum, Siprianus Edi: "Polda Riau Dinilai Ingkar Janji Dokumen Publik Ditutup", Oktober, 6 2016, <https://www.beritasatu.com/nasional/390848-polda-riaudinilai-ingkar-janji-dokumen-publik-ditutup.html>, [accessed, June 2019]

"Haze in Singapore: a problem dating back 40 years". (2015, October 2), https://www.straitstimes.com/singapore/environment/haze-in-singapore-aproblem-dating-back-40-years (accessed, 5 October 2018)

Hasan, Akhmad Muawal: "Kerap dituduh antek asing kepercayaan publik pada lsm turun", Maret, 12 2017, <https://tirto.id/kerap-dituduh-antek-asing-kepercayaanpublik-pada-lsm-turun-ckAb>, [accessed, July 2019]

Heilmann, D. (2015) 'After Indonesia's Ratification: The ASEAN Agreement on Transboundary Haze Pollution and Its Effectiveness As a Regional Environmental Governance Tool', Journal of Current Southeast Asian Affairs, 34, 3, pp. 95-121. Available at: http://nbn-resolving.org/urn/resolver.pl?urn:nbn:de:gbv:18-4-9073.

Hermawan, Bayu \& Fadhilah, Umi Nur: "Walhi SP3 Kasus Kebakaran Hutan Bukti Hukum Tumpul ke Atas", July, 25 2016, <https://nasional.republika.co.id/berita/nasional/hukum/16/07/25/oavf6o354walhi-sp3-kasus-kebakaran-hutan-bukti-hukum-tumpul-ke-atas, [accessed, June 2019]

Hidayat, Reja: "Kebakaran Hutan dan Hukum yang Timpang”, July, 26 2016, < https://tirto.id/kebakaran-hutan-dan-hukum-yang-timpang-bwoj> [accessed, June 2019]

"Hutan Terbakar, Staf Presiden Salahkan Pemda Telat Lapor". (2016, March 20), $<$ https://canindonesia.com/2016/03/hutan-terbakar-staf-presiden-salahkan-pemdatelat-lapor/>, [accessed, June 2019]

Index Mundi, Palm Oil Database, accessed from https://www.indexmundi.com/agriculture/?commodity=palm-oil\&graph=exports

Indriani, Citra: "Karhutla Terus Meluas Lahan Terbakar Mencapai 3.517 Hektar", July, 17 2019, <https://regional.kompas.com/read/2019/07/17/06405421/karhutla-riauterus-meluas-lahan-terbakar-mencapai-3517-hektar?page=all $>\quad$ accessed, July 2019]

“Jokowi: Kebakaran Hutan Bukan Tak Ada, tapi Turun Drastis". (2019, February 18), $<$ https://nasional.kompas.com/read/2019/02/18/12031191/jokowi-kebakaranhutan-bukan-tak-ada-tapi-turun-drastis >, [accessed, May, 1 2019]

"Kementerian Pertanian: Lahan Sawit Indonesia Capai 14,03 Juta Hektare". (2018, February <https://ekonomi.kompas.com/read/2018/02/26/203000426/kementerianpertanian--lahan-sawit-indonesia-capai-14-03-juta-hektare $\geq$ [accessed on 16 October 2018]

“Kue HUT Kabut Asap Riau Ke 17 Ditiup Sekdaprov”. (2016, March 14), <http://riauaktual.com/berita/detail/6255/kue-hut-kabut-asap-riau-ke-17-ditiupsekdaprov--.html\#.WF9vXbmzFuE>, [accessed on 16 October 2018].

Lee Poh Onn (2013) 'No end in sight to haze dilemma', ISEAS Perspective. (ISSN 23356677), 39. 
Lestari, Sri. (2015). Dampak kabut asap diperkirakan capai Rp.200 Trilliun. Accessed from:

https://www.bbc.com/indonesia/berita_indonesia/2015/10/151026_indonesia_kab utasap

Lin, Y., Wijedasa, L. S. and Chisholm, R. A. (2015) 'Singapore's willingness to pay for mitigation of transboundary forest-fire haze from Indonesia. Environmental Research Letters. Volume 12. Number 2.

"Malaysia Closes Schools as smoke from Indonesia forest". (2015, September 15), http://www.abc.net.au/news/2015-09-15/malaysia-closes-schools-as-indonesiasmoke-haze-worsens/6777508 [accessed 6 October 2018]"

"Mahkamah Agung vonis Presiden Joko Widodo melanggar hokum dalam kasus kebakakan hutan, KLHK akan ajukan PK”. (2019, July 20), <https://www.bbc.com/indonesia/indonesia-49041224>, [accessed, July 2019]

"Merdekakan sawit dari intervensi asing". (2016, August 17). $<$ https://gapki.id/news/1187/merdekakan-sawit-dari-intervensi-asing > , [accessed, July 2019]

Mina, Risno (2016) 'Desentralisasi Perlindungan dan Pengelolaan Lingkungan Hidup Sebagai Alternatif Menyelesaikan Permasalahan Lingkungan Hidup'. [accessed, May 2019]

Ministry of Forestry, Buku Basis Data Spasial Kehutanan 2013 (Jakarta: Kementerian Kehutanan, 2013)

Ministry of Forestry, Buku Basis Data Spasial Kehutanan 2014 (Jakarta: Kementerian Kehutanan, 2014)

Ministry of Forestry, Peta Indikatif Arahan Pemanfaatan Hutan pada Kawasan Hutan Produksi yang Tidak dibebani Izin untuk Usaha Pemanfaatan Hasil Hutan Kayu (Jakarta: Kementerian Kehutanan, 2014)

Mohd, K. et al. (2017) 'An overview of transboundary haze studies: The underlying causes and regional disputes on Southeast Asia Region An overview of transboundary haze studies: The underlying causes and regional disputes on Southeast Asia region', (December). doi: 10.11113/mjfas.v0n0.719.

Nazeer, N. et al. (2017) 'OVERVIEW OF ASEAN ENVIRONMENT , TRANSBOUNDARY HAZE POLLUTION AGREEMENT’, 13(1), pp. 73-94.

"Pakar: Asap Riau Terparah Sepanjang Sejarah". (2013, June 25), $<$ https://regional.kompas.com/read/2013/06/25/1129083/Pakar.Asap.Riau.Terpara h.Sepanjang.Sejarah $\geq$ [accessed on 16 October 2018]

Perwita, Nur Hidayah: "Kabut Asap Tipis Selimuti Pekanbaru-Dumai Akibat Karhutla", July, 14 2019, <https://tirto.id/kabut-asap-tipis-selimuti-pekanbaru-dumai-akibatkarhutla-eeeh>, [accessed, July 2019]

"PK Jokowi Di Kasus Karhutla Dinilai Bakal Sia-Sia”. (2019, July 21), <https://www.cnnindonesia.com/nasional/20190721180958-12-414149/pkjokowi-di-kasus-karhutla-dinilai-bakal-sia-sia , [accessed, July 2019]

"Perlawanan Jokowi setelah klah di meja kasasi soal kebakaran hutan". (2019, July 22), $<$ https://www.liputan6.com/news/read/4018212/perlawanan-jokowi-setelahkalah-di-meja-kasasi-soal-kebakaran- 
hutan?utm_expid=.9Z4i5ypGQeGiS7w9arwTvQ.0\&utm_referrer=https\%3A\%2F \%2Fwww.google.com\%2F>, [accessed, July 2019]

Pratama, Sandy Indra: "Penindakan korporasi pelaku kebakaran hutan tak serius", August, 24 2016, <https://www.hukumonline.com/berita/baca/lt57bd5416efc1e/walhi--penindakankorporasi-pelaku-kebakaran-hutan-tak-serius/> [accessed, June 2019]

Ramadhan, Ardito: "MA Tolak Kasasi Presiden Jokowi soal Kebakaran Hutan", July, 19 2019, <https://nasional.kompas.com/read/2019/07/19/17161121/ma-tolak-kasasipresiden-jokowi-soal-kebakaran-hutan>, [accessed, July 2019]

Roadmap. (2016), "Roadmap on ASEAN Cooperation Towards Transboundary Haze Pollution Control With Means of Implementation", http://haze.asean.org/wpcontent/uploads/2017/10/Roadmap-ASEAN-Haze-Free_adoptedbyCOP12.pdf [accessed, 5 October 2018]

Roda, Jean-Marc: "Geopolitics of palm oil and deforestation' July, 8 2019”, <https://www.thejakartapost.com/academia/2019/07/08/the-geopolitics-of-palmoil-and-deforestation.html>, [accessed, July 2019]

Safutra, Iham. (2017) Riau kembali diselimuti kabut asap. Accessed from: https://www.jawapos.com/jpg-today/09/06/2017/riau-kembali-diselimuti-kabutasap_[accessed, 16 October 2018]

Salim, Agus \&Burhani, Ruslan: "Presiden minta Gubernur-Wagub Riau Fokus Cegah Kebakaran Hutan", Februari, 20 2019, < https://www.antaranews.com/berita/800469/presiden-minta-gubernur-wagub-riaucegah-kebakaran-hutan> [accessed, June 2019]

Sarmiento, Prime (2015). "The Philippines hit by worst haze in 20 years", https://www.asianscientist.com/2015/11/features/philippines-worst-haze-20years/, [accessed on 16 October 2018]

Ser, J. et al. (2016) 'Environmental Science \& Policy Toward clearer skies : Challenges in regulating transboundary haze in Southeast Asia', Environmental Science and Policy. Elsevier Ltd, 55, pp. 87-95. doi: 10.1016/j.envsci.2015.09.008.

Simm, G. (2017), 'Disaster Response in Southeast Asia: The ASEAN Agreement on Disaster Response and Emergency Management', (December 2005), pp. 1-27. doi: $10.1017 / \mathrm{S} 2044251316000205$.

"Singapore smoke hits life-threatening levels, authorities attempting to 'seed' cloud". (2013, June 21). <https://www.rt.com/news/indonesia-wildfires-singapore-haze043/>, [accessed, 6 October 2018]

"Smog returns to Indonesia as fires rage". (2013, August 27), https://www.timeslive.co.za/news/sci-tech/2013-08-27-smog-returns-toindonesia-as-fires-rage/ [accessed, 6 October 2018]

Sudarsono: "kampanye hitam rugikan industri sawit Indonesia", September, 28 2018, <https://economy.okezone.com/read/2018/09/28/320/1956841/kampanye-hitamrugikan-industri-sawit-indonesia>, [accessed, July 2019]

Tan, S. and Ling, Y. (2017) 'The ASEAN Agreement on Transboundary Haze Pollution: exploring mediation as a way forward', 20, pp. 138-161.

Tanjung, Banda Haruddin: "Kebakaran Hutan dan Lahan di Riau capai 3.147 Hektar", June, 25 2019, 
<https://news.okezone.com/read/2019/06/25/340/2070746/kebakaran-hutan-danlahan-di-riau-capai-3-147-hektare>, [accessed, June 2019]

Tio \& Daryono: " MA tolak kasasi, ini kronologi awal hingga Jokowi dianggap bersalah", July, 192019 <https://www.tribunnews.com/nasional/2019/07/19/matolak-kasasi-ini-kronologi-awal-hingga-jokowi-dianggap-bersalah-dalam-kasuskebakaran-hutan?page $=4>$, [accessed, July 2019]

Tyson A, Varkkey H, Choiruzzad SAB. (2018) Deconstructing the Palm Oil Industry Narrative in Indonesia: Evidence from Riau Province. Contemporary Southeast Asia. 40 (3), pp. 422-448.

"Udara Pekanbaru Berbahaya, Senin Ini Sekolah Diliburkan". (2019, March 24), $<$ http://riaupos.co/44216-berita-udara-pekanbaru-berbahaya,-senin-ini-sekolahdiliburkan-.html\#.WF9uRbmzFuE>, [accessed on 16 October 2018]

Varkkey, Helena. (2014) 'Regional cooperation, patronage and the ASEAN Agreement on transboundary haze pollution', pp. 65-81. doi: 10.1007/s10784-013-9217-2.

Warsito, Budi. (2018). 5.376 Hektare Lahan di Riau Hangus Dilalap Si Jago Merah. Retrieved from: https://www.jawapos.com/jpg-today/30/09/2018/5376-hektarelahan-di-riau-hangus-dilalap-si-jago-merah_[accessed, 6 October 2018]

Wirawan, Jerome. (2016). Kabut asap selimuti Pekanbaru hingga Singapura. https://www.bbc.com/indonesia/berita_indonesia/2016/08/160826_indonesia_asa p_pekanbaru_singapura_[accessed, 6 October 2018]

World Bank Open Data, 2018, accessed from https://data.worldbank.org/indicator/EN.ATM.CO2E.KT [accessed, 6 October 2018]

World Bank, 2015, accessed from http://www.worldbank.org/in/news/feature/2015/12/01/indonesias-fire-and-hazecrisis [accessed, 6 October 2018]

WWF Indonesia, Palming Off a National Park: Tracking Illegal Oil Palm Fruit in Riau, Sumatra (Jakarta: WWF Indonesia, 2013)

Yugo, Okto. (2018). Perda RTRWP Riau cacat formal dan materil. Accessed from. http://jikalahari.or.id/kabar/berita/perda-rtrwp-riau-2018-2038-cacat-formal-danmateril/_[accessed, 6 October 2018]

Yumiko Uryu et. al, Sumatra's Forests, their Wildlife and the Climate (Jakarta: WWF Indonesia, 2010); Eyes on the Forest, 2018, "Sumatra's Forests, their Wildlife, and the Climate Online Database", accessed from http://maps.eyesontheforest.or.id/ [accessed, 10 October 2018]

Zuhri, Muhammad: "Foto Petinggi Polri Pesta Bareng Bos Pembakar Lahan SP3 beredar", September, 2 2016, < https://www.batamnews.co.id/berita-15951-fotopetinggi-polri-pesta-bareng-bos-pembakar-lahan-sp3-beredar.html>, [accessed, June 2019] 